\title{
Employment, Corporate Investment and Cash Flow Uncertainty
}

\author{
Sanjai Bhagat and Iulian Obreja* \\ Leeds School of Business \\ University of Colorado at Boulder
}

November 16, 2012

\begin{abstract}
In this paper we explore the role of cash flow uncertainty on corporate employment and corporate investment. We find that cash flow uncertainty has a significantly negative impact on corporate employment and corporate investment in both tangible and intangible assets. Furthermore, we find that this negative impact is significantly larger during recessions. Economically, if cash flow uncertainty were to revert to pre-recession levels, corporate employment would increase by more than 2.4 million jobs, investment in tangible assets would increase by $1.4 \%$, and investment in intangible assets would increase by $1.86 \%$. These findings could have policy implications.
\end{abstract}

\footnotetext{
${ }^{*}$ We would like to thank Anil Abbaraju for excellent research assistance with this project. We would also like to thank the seminar participants at the University of Colorado at Boulder and the participants in the micro-conference organized by AEI for their suggestions and comments. We would especially like to thank Adriana Kugler, Kenneth Lehn, Stan Veuger, Peter J. Wallison, Nick Bloom, and Steven J. Davis for excellent comments and suggestions that have greatly improved the paper. All errors are ours.
} 


\section{Introduction}

Business observers and policymakers have repeatedly raised concerns about the decrease in corporate investment activity during the ongoing financial and economic crisis that started in the fall of 2007. Given the direct and indirect effects of corporate investment in increasing employment, corporate investment is understandably of critical policy importance.

Corporate investment policy has been studied by corporate finance scholars for the better part of the past century. The net present value investment decision rule is a well-accepted paradigm. In the traditional paradigm, the value of corporate investment is a function of the project's expected cash flows and its opportunity cost of capital. The latter depends on the covariance of project's cash flows with investors' stochastic discount factor. In particular, the value of corporate investment depends not only on the first moment of the distribution of cash flows but also on higher moments. In spite of this simple observation, most of the empirical literature on the determinants of corporate investment is silent when it comes to the role of the higher moments of cash flow distribution. ${ }^{1}$

In this paper we study empirically the role of the second moment of the cash flow distribution for corporate investment in tangible and intangible assets as well as corporate employment.

The main challenge in addressing the role of higher moments of the distribution of future cash flow for corporate investment/employment is the measurement of these moments. We start with a simple theoretical framework to help us identify restrictions on the dynamics of a firm's future cash flows. Then we use these model restrictions to identify the time-series of innovations in a firm's cash flows in the data. We then project these implied innovations on variables that are likely to capture information about cash flow uncertainty, such as the volatility index, VIX. The end result is a time-varying estimate of the conditional volatility of a firm's cash flows. This estimate is a product of a time-invariant but firm-specific component (the coefficient from the projection) and a firm-invariant but time-varying component (e.g. VIX). We call this estimate the cash flow uncertainty measure, and we denote it with $\sigma_{i t}$.

In our theoretical framework, firms use capital and labor as inputs of production. Workers are paid competitive wages (cost of labor) that reflect the firm's demand for labor as well as the consumers/investors' willingness to supply the necessary labor. Firms carry a stock of capital and operate at full capacity facing fixed production costs. Consumers/investors earn wages from the supply of labor in one firm, and they earn dividends (financial income) from their ownership of the rest of the firms in the economy. Consumers/investors decide how much labor to supply, where to allocate their financial wealth, and whether to increase or decrease the production capacity of the firms that they own.

\footnotetext{
${ }^{1}$ See King and Rebelo (2000) for a recent survey of the financial economic literature on the role of cash flow uncertainty in corporate investment.
} 
This framework yields two interesting results. The first one is that the dynamics of a firm's cash flows have a predictive component that depends linearly on lagged cash flows and non-linearly on the firm's marginal q, cost of labor, and aggregate demand for output product. In addition, the innovations in cash flows are related to either innovations in the cost of labor or innovations in the fixed production costs. The second result is that corporate investment depends nonlinearly on marginal q and, separately, on the cost of labor, and it depends linearly on the firm's current cash flow. In addition, the cost of labor is fully determined by the capital stock and the aggregate demand for the output product, and, through this channel, corporate investment becomes also related to lagged corporate investment decisions.

Turning to the empirical part of the paper, we use the first result to construct our empirical measure of cash flow uncertainty, $\sigma_{i t}$, and then we use the second result to assess the role of $\sigma_{i t}$ for corporate investment.

Regarding the construction of the uncertainty measure $\sigma_{i t}$, the theoretical restrictions on the dynamics of firm cash flows (the first result above) suggest that innovations in cash flows can be recovered as the residuals of a within-industry dynamic panel data model of firm cash flows which allows explicitly for time-variation in production input levels and prices (these explanatory variables are available at industry level). We use this approach to identify the innovations in cash flows and then we follow the steps discussed above to construct the cash flow uncertainty measure $\sigma_{i t}$.

Regarding the role of cash flow uncertainty in determining corporate investment, our model suggests (the second result above) that the only way $\sigma_{i t}$ can impacts corporate investment is through the firm's marginal q. This means that if we want to study the empirical relationship between cash flow uncertainty and corporate investment we have to control for marginal q. Furthermore, according to our theoretical result, marginal q is not the only determinant of corporate investment, and, in particular, we have to control also for the level of firm's cash flow as well as lagged corporate investment decisions. To this end, we follow Hennessy (2001) and use the firm's Tobin's Q and its book leverage ratio as proxy for marginal q. We then estimate the empirical relationship between corporate investment and the cash flow uncertainty measure $\sigma_{i t}$ in a dynamic panel data model with explicit controls for a firm's Tobin's Q, book leverage, internal cash, and free cash flow (the last two variables of firm cash flows are defined as in Leahy and Whited (1996)).

Before we present the main empirical findings, we want to point out that besides measuring cash flow uncertainty and studying the relationship between this measure and corporate investment, our study also expands the definition of corporate investment to include not only investment in tangible assets but also investment in intangible assets and also corporate employment (as a proxy for investment in human capital). We measure investment in intangible assets as the percentage change in the stock of intangible capital and corporate employment change as the percentage change in the number of employees. We construct the stock of intangible capital using traditional macroeconomic techniques that account explicitly for research and development expenditures and capitalized intangibles. 
We use both corporate investment in tangible and intangible assets as well as corporate employment to study the impact of cash flow uncertainty on corporate investment. ${ }^{2}$

Our main empirical findings are as follows: First, there is a strong and negative relationship between the cash flow uncertainty measure $\sigma_{i t}$ and corporate investment in either tangible or intangible assets. This relationship is robust to controls for marginal q and firm's cash flow, to firm-fixed effects and time-fixed effects, to whether the estimation model is dynamic or passive, and to endogeneity specifications for the dynamic model. Second, there is a strong and negative relationship between $\sigma_{i t}$ and the corporate employment change. This relationship is robust to the same changes in specifications/methodology as before. Third, and final, the impact of $\sigma_{i t}$ on either corporate investment or employment is significantly stronger during the period following the financial crisis of 2007-2008 than during the period leading up to this crisis.

To get a sense of how strong these relationships are we perform the following heuristic experiment. Suppose that the level of average cash flow uncertainty were to drop from the level observed in 2009 (a post-crises level of cash flow uncertainty that is particularly elevated) to the level observed back in 2005 (a pre-crisis level). How much would corporate investment and employment change as a result of the drop in cash flow uncertainty, holding everything else constant? We obtain, that corporate investment in tangible assets would increase by $1.4 \%$, corporate investment in intangible assets would increase by $1.86 \%$, and, finally, corporate employment would increase by more than 2.4 million jobs (or equivalently corporate employment change would increase by $1.87 \%$ ).

These numbers suggest that cash flow uncertainty has a significant impact on corporate investment at all levels. Furthermore, corporate investment in intangible assets and corporate employment are especially sensitive to changes in cash flow uncertainty. Overall, the magnitude of these numbers suggests that decreasing cash flow uncertainty at the times of duress can greatly improve the overall economy by stimulating corporate investment and employment.

We run several additional robustness tests to see whether our results stem from a potential connection between the projecting variable, namely VIX, that is crucial in the construction of $\sigma_{i t}$, and the overall corporate investment and employment activity. In particular, we use the policy uncertainty index of Baker, Bloom and Davis (2011) as an alternative to VIX and find that the new measure of cash flow uncertainty (that is based on the policy uncertainty index) is still strongly negatively related to both corporate investment and employment. Furthermore, when performing the heuristic exercise above using this new

\footnotetext{
${ }^{2}$ The literature on corporate investment addresses usually investment in tangible assets. Important contributions to this literature include Kaplan and Zingales (1997), Fazzari, Hubbard, and Petersen (1998), Whited and Wu (2006), and Duchin, Ozbas, and Sensoy (2010). The extant literature on corporate investments in intangible assets is comparatively quite modest. Important contributions include Bhagat and Welch (1995) and Fee, Hadlock, and Pierce (2009). However, even these papers consider but subsets of intangible assets; for example, Bhagat and Welch consider R\&D investments, whereas Fee, Hadlock and Pierce focus on advertising expenditures.
} 
measure of firm cash flows we find similar magnitudes. We consider also other alternatives for the projecting variables as well as other estimation techniques and in all cases we find that cash flow uncertainty has always a strong and negative impact on both corporate investment or employment.

These findings have significant policy implications; if policy makers would like corporations to increase their investment activity, they should focus on policies that decrease corporate cash flow uncertainty. Specifically, to the extent corporations are uncertain about the implementation and the implementation-timeline of the health reform act, and the impact of this act on their costs of hiring and retaining employees - a clarification of the implementation and the implementation-timeline of the health reform act would encourage corporations to invest more and hire more employees. Similarly, to the extent corporations are uncertain about the implementation and the implementation-timeline of the environmental cap-and-trade reform and corporate tax reforms - a clarification of the implementation and the implementation-timeline of these environmental and tax reforms would encourage corporations to invest more and hire more employees.

The relationship between investment and uncertainty has been the focus of many theoretical and empirical studies for the past 50 years. From a theoretical standpoint, the literature has reached the consensus that the sign of the investment-uncertainty relationship is positive if the marginal revenue product of capital is convex in productivity shocks - this is known in the literature as the Hartman-Abel-Caballero effect - and negative if investment is partially irreversible and the marginal revenue product of capital is concave in productivity shocks. ${ }^{3}$ From an empirical standpoint, most of the evidence seems to support a negative investment-uncertainty relationship. ${ }^{4}$

Our paper differentiate on several levels from the extant empirical literature on the relationship between investment and uncertainty. Unlike most empirical studies in this literature, our measure of cash flow uncertainty is not based on firm-level equity returns, but rather on projecting variables such as VIX that are not directly related to corporate investment/employment decision in one particular firm. In particular, our cash flow uncertainty measure is less prone to endogeneity issues that arise in studies that use risk measures based on firm-level equity returns. ${ }^{5}$

The remainder of the paper is organized as follows. Section II develops our model of the production economy and motivates our measure of cash flow uncertainty. Section III

${ }^{3}$ For models that predict a positive investment-uncertainty relationship see Hartman (1972), Caballero (1991), Abel (1983), Abel (1984), and Abel (1985). For models that predict a negative investment-uncertainty relationship see Pindyck (1988), McDonald and Siegel (1985), McDonald and Siegel (1986), Dixit and Pindyck (1994), Saltari and Ticchi (2007).

${ }^{4}$ See for instance Leahy and Whited (1996), Bulan (2005), Shaanan (2005), Bloom, Bond, and van Reenen (2007), Bloom (2009) and Panousi and Papanikolaou (2010). These studies also provide extensive literature review.

${ }^{5}$ There is an extensive literature documenting a strong link between investment post stock performance (including stock volatility). See for instance Anderson and Garcia-Feijoo (2006) and Cooper, Gulen, and Schill (2008). 
estimates the cash flow uncertainty measure in the data. Section IV investigates empirically the relationships between corporate investment or employment and our measure of cash flow uncertainty. Section $\mathrm{V}$ investigates these relationships around the late financial crisis of 2007-2008. Section VII discusses the various robustness checks that we perform. Finally, Section VII concludes with a discussion of our results.

\section{A dynamic model of firm cash flows}

Consider a perfectly competitive economy populated by many identical firms and many identical investors/consumers. Firm output, $y_{t}$, is given by a standard neoclassical constant returns-to-scale production function that uses as inputs capital, $k_{t}$, and labor, $l_{t}^{D}$

$$
y_{t}=F\left(k_{t}, l_{t}^{D}\right) .
$$

The firm takes output prices, $p_{t}$, as given, so that its revenues equal $p_{t} y_{t}$. The market for labor is competitive and the firm pays competitive wages, $w_{t}$, per unit of labor. The firm faces also fixed production costs that take the following form

$$
\left[\Phi+\epsilon_{t}\right] k_{t}
$$

where $\epsilon_{t}$ is an i.i.d random production cost shock with mean zero. We assume that the firm's capital depreciates at a rate $\delta$. Let $\tau$ denote the marginal tax rate on corporate profits. Then the firm's free cash flows can be computed with the following formula

$$
\pi_{t}=(1-\tau)\left[p_{t} y_{t}-w_{t} l_{t}^{D}-\left(\Phi+\epsilon_{t}\right) k_{t}\right]+\tau \delta k_{t} .
$$

Firms are owned by investors/consumers who decide every period how much to consume, how much to work, and how much to invest in the firm to maximize their life-long utility

$$
\max _{c_{t}, l_{t}^{S}, x_{t}, \theta_{t}} \sum_{t=0}^{\infty} \beta^{t} E\left[u\left(c_{t}, l_{t}^{S}\right)\right],
$$

subject to the budget constraint

$$
c_{t}+\theta_{t} P_{t} \leq w_{t} l_{t}^{S}+\theta_{t-1}\left[P_{t}+\left(\pi_{t}-x_{t}\right)\right],
$$

where $x_{t}$ is the amount of new capital that investors/consumers decide to add to the firm's capital stock, and $\pi_{t}-x_{t}$ is the dividend paid out by the firm. We assume that the utility function $u$ takes the following form

$$
u\left(c_{t}, l_{t}^{S}\right)=U\left(c_{t}-G\left(l_{t}^{S}\right)\right),
$$

where the univariate functions $U$ and $G$ satisfy the usual regularity conditions. We assume that the firm's capital stock follows the dynamics

$$
k_{t+1}=(1-\delta) k_{t}+x_{t}
$$


Firms decide every period how much labor to use in the production

$$
\max _{l_{t}^{D}} \pi_{t}
$$

In particular, notice that the firm delegates its investment decision to investors/consumers.

In equilibrium, in each period $t$, we must have that demand for labor equals the supply of labor $l_{t}^{D}=l_{t}^{S}$, and that investors/consumers hold the entire supply of firm's stock, $\theta_{t}=1$.

The producers' first order condition is

$$
w_{t}=p_{t} F_{2}\left(k_{t}, l_{t}^{D}\right)
$$

Similarly, the investor/consumer first order conditions are

$$
\begin{aligned}
u_{1}\left(c_{t}, l_{t}^{S}\right) w_{t} & =-u_{2}\left(c_{t}, l_{t}^{S}\right) \\
u_{1}\left(c_{t}, l_{t}^{S}\right) & =q_{t},
\end{aligned}
$$

where $q_{t}$ is the Lagrange multiplier of the capital stock dynamics equation. Exploiting the separability of labor and consumption in the utility function, we obtain the following equilibrium equations

$$
\begin{aligned}
w_{t}^{\nu} & =k_{t}\left[\frac{1}{(1-\alpha) p_{t}}\right]^{-\frac{1}{\alpha}} \\
l_{t}^{S} & =l_{t}^{D}=w_{t}^{\frac{1}{\theta}} \\
x_{t} & =\frac{\theta}{1+\theta} w_{t}^{\frac{\theta}{1+\theta}}-q_{t}^{-\frac{1}{\gamma}}+\pi_{t},
\end{aligned}
$$

where $\nu=\frac{1}{\theta}+\frac{1}{\alpha}$.

The first equation determined the optimal wage rate, $w_{t}$, as a function of contemporaneous capital stock and output prices. The second equation describes the equilibrium demand and supply of labor as a function of wage rate. Finally, the equilibrium investment rate is a function of the firm's contemporaneous cash flow, $\pi_{t}$, and marginal $q, q_{t}$, and also equilibrium wage rate, $w_{t}$.

An important consequence of the last of these equilibrium equations, is that the relationship between corporate investment and marginal $\mathrm{q}$ is positive and highly non-linear. Corporate investment is also positively related to the firm's contemporaneous cash flow, the aggregate demand for the firm's output good (through equilibrium wages), and the level of capital stock. In particular, corporate investment is positively related to lagged corporate investment.

Substituting these formulas back into the equation for $\pi_{t}$, and using again the capital stock dynamics equation we obtain the following dynamics for the the shadow cost of capital

$$
q_{t}=\beta E_{t}\left[q_{t+1} G\left(w_{t+1}, p_{t+1}, \epsilon_{t+1}\right)\right],
$$


and the following dynamics for the firm's cash flows

$$
\pi_{t+1}=\rho \pi_{t}-\rho q_{t}^{-\frac{1}{\gamma}}+H\left(w_{t}, p_{t}\right)+\alpha \frac{1-\tau}{1-\alpha}\left[w_{t+1}^{\frac{\theta}{1+\theta}}-w_{t}^{\frac{\theta}{1+\theta}}\right]-(1-\tau) k_{t+1} \epsilon_{t+1},
$$

where $\rho=\tau \delta-(1-\tau) \Phi$. The derivations of these formulas along with the definitions of functions $H$ and $G$ are in the Appendix.

The last equation says that firm's cash flows are determined by the firm's lagged cash flows, $\pi_{t}$, the firm's shadow cost of capital, $q_{t}$, the cost of labor, $w_{t}$, the current demand, $p_{t}$, and, finally, innovations in the cost of labor, $w_{t+1}^{\frac{\theta}{1+\theta}}-w_{t}^{\frac{\theta}{1+\theta}}$, and non-labor production costs, $\epsilon_{t+1}$.

Our goal in this paper is to construct a time-varying measure of a firm's cash flow uncertainty. To this end the above equation is useful because it tells us how to uncover the shocks in firm cash flows. Namely, these shocks are the residuals of a dynamic model of firm cash flows after controlling for firm variables such as labor cost, demand, and the cost of capital. The next section attempts to do just that.

\section{Measuring cash flow uncertainty}

The model in the previous section has an important prediction for the dynamics of firm cash flows. Namely, that the change in cash flows from one production period to the next depends on two terms: on the one hand the level of cash flows from last production period (scaled down by a positive constant less than 1), and, on the other hand, a cumulative sum of innovations in cost of labor, variable cost of production (e.g. cost of non-labor production factor inputs), and productivity of new capital relative to vintage capital. If we denote with $\bar{\epsilon}_{i(t+1)}$ the vector of unit-variance innovations in the second term, and with $\sigma_{i t}^{\prime} \bar{\epsilon}_{i(t+1)}$ the second term, we can restate this prediction as follows

$$
C F_{i(t+1)}-C F_{i t}=\lambda C F_{i t}+\Sigma_{i t} \bar{\epsilon}_{i(t+1)},
$$

where $\lambda$ is a constant.

In this section we use this equation to guide us in extracting innovations in firm cash flows, and then to estimate the conditional variance of these shocks. According to the restriction above, we should be able to identify cash flows innovations only after we take into account the dynamic nature of firm cash flows. In addition, rather than restricting $\lambda$ to be the same across all firms, we allow $\lambda$ to vary across industries. That is we replace $\lambda$ with $\lambda_{J}$, where $J$ is an index for industries.

Empirically, one way to implement these two observations is to model firm cash flows using a within-industry dynamic panel data model. Along these lines, we use the following specification

$$
\frac{C F_{i(t+1)}}{B A_{i(t+1)}}=\left(1-\lambda_{J}\right) \frac{C F_{i t}}{B A_{i t}}+\gamma_{J} X_{i t}+\delta_{i}+\epsilon_{i(t+1)},
$$


where $X_{i t}$ is a vector of variables that contain information about firm productivity, cost of labor and non-labor factors of production, $\delta_{i}$ is a dummy for unobservable firm-specific fixed effects, and the errors $\epsilon_{i(t+1)}$ are i.i.d with zero mean and conditional variance $\Sigma_{i t}^{2}$.

A few comments are in effect. First, unlike the model restriction (14), our empirical specification in (15) scales cash flows by book assets. This helps improve the fit of our model, as scaled cash flows are substantially less volatile within-industry than plain vanilla cash flows. Second, our specification takes into account that to the extent that our cash flow dynamics are misspecified, the variables whose innovations make up the second term in equation, and which we denote collectively with $X_{i t}$, might affect cash flows directly. Finally, since all variables considered here are endogenous to the firm, we have to allow for potential unobserved firm fixed effects.

Once we extract the errors $\epsilon_{i t}$, we estimate the firm-specific conditional variance $\Sigma_{i t}$ using a simple linear projection. That is, suppose that $Z_{t}$ is a vector of variables that are informative about cash flow risk (we discuss below the choice of the variables $Z_{t}$ ). Then, for each firm $i$, we regress the squared fitted errors from the dynamic panel data model on $Z_{t}$,

$$
\hat{\epsilon}_{i(t+1)}^{2}=\eta_{i 0}+\eta_{i}^{\prime} Z_{t}+\nu_{i(t+1)},
$$

where $\nu_{i t}$ are i.i.d errors with zero mean. By definition, $\Sigma_{i t}^{2}=E_{t}\left[\epsilon_{i(t+1)}^{2}\right]$, and we can estimate $\sigma_{i t}$ using the formula

$$
\hat{\Sigma}_{i t}^{2}=\hat{\eta}_{i 0}+\hat{\eta}_{i}^{\prime} Z_{t}
$$

While we find that $\hat{\eta}_{i}$ is positive for almost all firms $i$ in our sample, $\hat{\eta}_{i 0}$ can be occasionally negative. In particular, $\hat{\Sigma}_{i t}^{2}$ may fall below zero for certain times $t$, and therefore our interpretation of $\hat{\Sigma}_{i t}^{2}$ as a conditional variance is not appropriate. To avoid this issue, we define our cash flow uncertainty measure as follows:

$$
\sigma_{i t}=\sqrt{\hat{\Sigma}_{i t}^{2}-\hat{\eta}_{i 0}}=\sqrt{\hat{\eta}_{i}^{\prime} Z_{t}}
$$

Our goal is to study the relationship between investment and lagged cash flow uncertainty. In particular, the time-varying component of cash flow uncertainty is clearly important. To this end, notice that $\sigma_{i t}^{2}$ is obtained by shifting the estimate of the conditional variance of cash flows, $\hat{\Sigma}_{i t}^{2}$, by a firm-specific constant (i.e. $\hat{\eta}_{i 0}$ ), while retaining intact the timevarying component of $\hat{\Sigma}_{i t}^{2}$.

We now discuss the choice of projection variables $Z_{t}$. The defining property of $Z_{t}$ is that they have to contain information about the conditional variances of future cash flows. A natural candidate for $Z_{t}$ is the firm-specific annual stock return volatility. However, since our ultimate goal is to analyze the relationship between investment and cash flow uncertainty, we have to be mindful of whether the projection variables $Z_{t}$ are not themselves endogenously related to corporate investment. For instance, to the extend that a firm precommits in advance to its investment plans - which is typically the case in the real world-, its stock returns will reflect these growth plans before the firm makes the actual investment. Consequently, a cash flow uncertainty measure based on stock return volatility 
from stock prices prior to the actual investment, will reflect information about investment. This link will bias the relationship between cash flow uncertainty as measured by stock return volatility and corporate investment. There are several studies that use stock return volatility as proxy for risk and study the relationship between corporate investment and risk. These studies do not agree on the sign of the relationship between investment and risk, and not even on whether there is such a relationship at all.

To avoid this severe endogeneity problem, we choose to focus on variables $Z_{t}$ that are not firm specific, yet still capable of capturing some information about cash flow risk. We choose $Z_{t}$ to be VIX - the S\&P 500 volatility index that trades on CBOE. VIX measures the implied volatility of S\&P 500 Index from the prices of S\&P 500 index options. Unlike idiosyncratic stock return (realized) volatility, VIX is less likely to be impacted by investment precommittment announcement of any of the firms in the S\&P 500 Index, because the impact of such an announcement on index levels or returns is dampened by the weight of the firm in the index. In a later section, we also consider several alternatives to VIX, and show that the main results, which we will present in the next section, still obtain.

Our sample consists of all COMPUSTAT firms between 1986 and 2011. We focus on this time period because of the availability of price data for VIX. However, later on, when we consider alternatives to VIX that have longer lifespans, we extend the sample period as well. We emphasize that our sample considers firms from all available industries, including financials, leasing, insurance, real estate etc. We do this because we plan to study the impact of cash flow uncertainty not only on traditional corporate investment in tangible assets, but also corporate investment in intangible assets and human capital as well. While investment in tangible assets is not necessarily well defined for non-manufacturing industries (once we exclude real estate property and computer equipment), investment in human capital is certainly well defined for all industries.

Traditional variables such as book assets, capital stock, investment in tangible assets etc. are defined using the standards in the corporate finance literature. New variables such as investment in intangible assets or human capital will be defined along the way. For convenience we include an appendix with the definitions of all variables .

As mentioned above, the first step in constructing the cash flow uncertainty measure $\sigma_{i t}$ is to estimate the dynamic panel data model (15). We define cash flows $C F_{i t}$ as EBITDA. $X_{i t}$ is a vector of variables that are informative about factor productivity, cost of labor (e.g. wages, salaries and other benefits etc), and cost of non-labor factors of production (e.g. energy, raw materials and commodities etc). The vector $X_{i t}$ include the following variables: multi-factor productivity, output per unit of capital, output per hour of labor, sectoral output, capital services, labor hours, cost of labor, and cost of combined inputs. All these variables come from NIPA Industry Database and are only available at annual frequency and aggregated at the industry level. ${ }^{6}$ We also use the standard industry classification used in NIPA tables.

\footnotetext{
${ }^{6}$ Access to the NIPA Industry Database can be obtained through the Bureau of Labor Statistics' website, namely http://www.bls.gov/mfp.
} 
We estimate the dynamic panel data model (15) within each industry. We use the method proposed by Arellano and Bond (1991) with the assumptions that multi-factor productivity, output per unit of capital, and output per hour of labor are exogenous, while the rest of the variables in $X_{i t}$ are endogenous. We choose to specify multi-factor productivity, output per unit of capital, and output per hour of labor as exogenous, because they all reflect the efficiency of the technology used by the firm rather than the managerial decisions of the firm. In a later section, we show that our main results still obtain when we change these assumptions.

Once we obtain the cash flow innovations from (15), we estimate (16) firm by firm, and then construct our measure of cash flow uncertainty $\sigma_{i t}$. Figure 3 plots the annual crosssectional median of this cash flow uncertainty measure. We notice that cash flow uncertainty is particularly high during economic downturns.

The next section explores the empirical relationship between cash flow uncertainty and corporate investment.

\section{Relationships between $\sigma_{i t}$ and corporate investment and employment}

Unlike most empirical tests on the relationship between corporate investment and uncertainty, we expand the scope of the notion of corporate investment and consider investment in both tangible assets and intangible assets unrelated to human capital. In addition, we also consider corporate employment as a proxy for investment in human capital. In sections B. and C. below, we discuss in more detail how we measure investment in intangible capital and corporate employment.

The model in Section II constraints the dynamics of optimal corporate investment to be a function of several determinants, namely the firm's marginal q, the contemporaneous cash flow, the level of capital stock, and the output prices (or aggregate demand for the output good). This result has two important implications for our empirical analysis. On the one hand, it says that the optimal corporate investment does not depend exclusively on the firm's marginal q - as the q-theory of investment predicts - but it depends also on other firm variables such as firm cash flow. On the other hand, the only way optimal corporate investment relates to cash flow uncertainty is through the firm's marginal q. This happens because with the exception of marginal $q$ all the other determinants of corporate investment (mentioned above) can be computed without forming explicit expectations about future cash flows. However, to compute marginal $q$ we need to form expectations about what determines marginal $\mathrm{q}$ in the future - such as the distribution of future cash flows - (see equation (12)). In particular, marginal q depends on the standard deviation of the firm's future cash flows, $\sigma_{i t}$, that we define in the previous section.

In our model we see think of corporate investment in a broader sense which includes in- 
vestment in both tangible and intangible assets, as well as investment in human capital. ${ }^{7}$ For the rest of the paper we want to investigate empirically whether there is a relationship between corporate investment or employment and cash flow uncertainty, $\sigma_{i t}$. According to our model cash flow uncertainty should affect corporate investment/emplyment though marginal q. In particular, we cannot study the relationship between corporate investment and $\sigma_{i t}$ in isolation, but rather on the margin, that is, we can only study whether $\sigma_{i t}$ determines corporate investment above and beyond marginal $\mathrm{q}$ and other known determinants of corporate investment (e.g. cash flow measures). This approach to studying this relationship is similar in spirit to the approach suggested in Leahy and Whited (1996).

Our empirical models below take these considerations into account. In particular, we use Tobin's $\mathrm{Q}, \mathrm{MA}_{i t} / \mathrm{BA}_{i t}$, to proxy for marginal q, and we use two cash flow measures, namely cash flows to capital ratio, $\mathrm{CF}_{i t} / \mathrm{K}_{i(t-1)}$, and cash to assets ratio, $\mathrm{Ca}_{i t} / \mathrm{BA}_{i t}$, to capture the potential dependence of corporate investment on contemporaneous cash flows.

We consider two basic approaches to testing the empirical relationship between corporate investment or employment and cash flow uncertainty. The first approach is a standard panel data regression with controls for business cycle, investment opportunities, and financing constraints. This approach relies on unobserved firm-fixed effects and time-fixed effects to cope with potential endogeneity inherent in most variables considered. In addition to Tobin's Q and the two cash flow measure discussed above, we also use real GDP annual growth rate, $g_{t}$, as a proxy for business cycle. We also use book leverage ratio, $\mathrm{BD}_{i t} / \mathrm{BA}_{i t}$, to allow for the possibility that investment depends on financing constraints. To simplify the exposure, we group all these firm variables in a vector $\mathrm{v}_{i t}$.

Let $x_{i(t+1)}$ denote either corporate investment or employment over the production cycle $(t, t+1)$. Then, our panel data regression has the following specification

$$
x_{i(t+1)}=a_{0}+a_{1} \sigma_{i t}+a_{2} g_{t}+a_{3}^{\prime} \mathrm{v}_{i t}+u_{i}+\delta_{t}+\epsilon_{i t+1} .
$$

The second approach that we consider to investigate the relationship between cash flow uncertainty and corporate investment/employment is based on a dynamic panel data model. The general specification of this model takes the following form

$$
x_{i(t+1)}=b_{0}+b_{1} x_{i t}+b_{1} \sigma_{i t}+b_{2} g_{t}+b_{3}^{\prime} \mathrm{v}_{i t}+u_{i}+\delta_{t}+\epsilon_{i t+1} .
$$

This model is estimated using the GMM methodology of Arellano and Bond (1991) and it assumes that the vector of variables $v_{i t}$ is endogenous while the business cycle variable $g_{t}$ is exogenous. We consider two specifications of this model depending on whether cash flow uncertainty, $\sigma_{i t}$, is assumed exogenous or endogenous.

\footnotetext{
${ }^{7}$ In the model both firms and consumers make decisions about the demand and supply of labor hours, respectively. We view this labor demand/supply decision as being different than the investment in human capital. That is, consumers can choose to invest in human capital just as they choose to invest in either tangible or intangible assets.
} 


\section{A. Corporate investment in tangible assets}

We first study the empirical relationship between our measure of cash flow uncertainty, $\sigma_{i t}$, and corporate investment in tangible assets. Like most of the corporate finance literature on corporate investment, we measure corporate investment in tangible assets as the ratio of capital expenditures for the production period $(t, t+1)$ to the capital stock at the beginning of this production period. However, unlike most studies in this literature, we expand the scope of our analysis and include all available industries for our sample period. In particular we include industries such as financials, leasing, insurance, real estate etc.

We report the results in Table II. As mentioned above, we use two methods to estimate the relationship between corporate investment in tangible assets and cash flow uncertainty. For the first method - described in (18) - we estimate two specifications which differ only in whether we include time dummies or not. Column I presents the results of the specification without time dummies while column II presents the ones of the specification with time dummies. For the second method - described in (19) - we consider two dynamic models, depending on whether the cash flow uncertainty measure, $\sigma_{i t}$, is assumed exogenous or endogenous (columns V and VI). For each of these dynamic models, we estimate two specifications which, as before, differ only in whether we include time dummies or not. Columns III and IV present the results of the dynamic model with exogenous $\sigma_{i t}$, under the specifications without and with time dummies, respectively. Similarly, columns V and VI present the results of the dynamic model with endogenous $\sigma_{i t}$, under the specifications without and with time dummies, respectively.

The results of Table II show that, regardless of the method or the specification used, the relationship between investment in tangible assets and cash flow uncertainty is always strongly negative. The strength of this relationship, as measured by the coefficient in front of $\sigma_{i t}$, depends on the method and the specification used. In particular, and maybe not surprisingly, within the specifications with time-fixed effects, the strength of the relationship between corporate investment and cash flow uncertainty diminishes to some extent. However, even within these specifications, the relationship remains strong, both statistically and economically. This observation is important because the time variation in $\sigma_{i t}$ comes entirely from VIX, and one might suspect that the relationship between corporate investment and $\sigma_{i t}$ shows up in our results because of the years when VIX is particularly elevated (e.g. around economic recessions). The fact that we find a strong relationship between investment and cash flow uncertainty, even after controlling for time-fixed effects, suggests that our measure of uncertainty, $\sigma_{i t}$, captures more than just time-specific economy-wide events.

The GMM estimates of the $\sigma_{i t}$ coefficient from dynamic panel data models - specifications III to VI - rely on over-identifying moment restrictions. To test for the validity of the overidentifying moment restrictions we employ the standard Sargan test. We notice that for all specifications the Sargan test is significantly different from zero, and, therefore the

validity of the over-identifying moment restrictions cannot be rejected. Incidentally, we 
also notice that across all specifications, the test of joint significance of the independent variables comes up always significant.

Another interesting take away from this table is the relationship between corporate investment and the GDP growth, $g_{t}^{G D P}$. For all specifications, this relationship is strong and positive. That is to say, an increase in GDP growth stimulates positively corporate investment in tangible assets. In the neoclassical growth model, and therefore in our model as well, GDP growth is associated with aggregate output growth. In particular, $g_{t}^{G D P}$ and cash flow growth are related. From this perspective, one can think of $g_{t}^{G D P}$ and $\sigma_{i t}$ as complements: while $g_{t}^{G D P}$ is informative about the conditional mean of cash flows, $\sigma_{i t}$ is informative about their conditional variance. Thus, the relationships between corporate investment and either $g_{t}^{G D P}$ or $\sigma_{i t}$ suggest that an increase in the conditional mean of firm cash flows has a positive impact on corporate investment in tangible assets, while an increase in the conditional variance of firm cash flows has a negative impact.

To better grasp the economic impact of these empirical relationships, we propose a simple numerical experiment. Suppose that the average cash flow uncertainty were to drop from its 2009 level to a pre-crises level, say 2005. Then the average corporate investment in tangible assets would increase by $1.4 \% .{ }^{8}$ Similarly, if the GDP growth rate in 2009 were to drop to the GDP growth rate of 2005 , the average corporate investment would increase by $1.37 \%$, in absolute terms, and by $9.78 \%$, relative to the investment in $2009 .{ }^{9}$

\section{$B$. Investment in intangible assets}

Many of the results of the previous section can be extended to intangibles investment as well. However, before we present our empirical findings, we discuss our measure of intangibles capital.

The lack of detailed data on investments in intangible assets complicates tremendously the task of measuring the stock of intangibles capital. Macroeconomist and financial economists alike recognize the severity of the problem, yet there are only a handful of studies focusing exclusively on the issue of measuring intangibles capital. Important contributions to the literature include Hall (2001), McGrattan and Prescott (2005b), McGrat$\tan$ and Prescott (2005a) etc. Most of these studies estimate the U.S. aggregate stock of intangibles capital from real business cycle models constraint to fit aggregate moments of corporate activity from the NIPA tables. However, this approach is difficult to use at firm

\footnotetext{
${ }^{8}$ Based on the times series of cross-sectional averages of investment and uncertainty measures in Figures 3 and 1, we notice that between 2005 and 2009 average investment in tangible assets dropped from $25.47 \%$ to $18.83 \%$, while average $\sigma$ increased from $2.76 \%$ to $4.36 \%$. Thus, if $\sigma$ were to drop to the 2005 level, investment would increase by $-0.880 \times(2.76 \%-4.36 \%)=1.4 \%$. Relative to the level of corporate investment in 2009, this increase becomes $1.4 \% / 18.83 \%=7.48 \%$.

${ }^{9}$ Following the approach from the previous footnote, GDP growth rate drops from $2.69 \%$ in 2005 to $0.19 \%$ in 2009 . In particular, if $g_{t}^{G D P}$ were to increase to the 2005 level, investment would increase by $0.547 \times(2.69 \%-0.19 \%)=1.37 \%$.
} 
level because some of the aggregate quantities in the NIPA tables are not available at firm level.

From an accounting perspective, it is well known that certain investments in intangibles assets can be capitalize - such as goodwill from firm acquisitions, patents, rights, etc while others can only be expensed - such as research and development. This means that the book value of intangibles assets acquired through capitalized investments should be on the balance sheet, while the book value of intangible assets acquired through expensed investments should not. Therefore, the challenge is to measure the book value of intangibles assets that are not on the balance sheet.

Our view is that a good measure of the stock of intangible capital should reflect the book value of both types of intangible assets, namely those that are acquired through capitalized investments and those that are acquired through expensed investments. Therefore, we propose the following measure of intangibles capital

$$
k_{i t}^{I}=\left(\mathrm{TA}_{i t}-\mathrm{CA}_{i t}-\mathrm{PPENT}_{i t}\right)+\sum_{s=t-T}^{t}\left(1-\delta^{I}\right)^{t-s} \mathrm{R}^{t} \mathrm{D}_{i s},
$$

where TA, CA, PPENT, and R\&D stand for total book assets, total current assets, net property, plant, and equipment, and research and development, respectively. $\delta^{I}$ is the depreciation rate on $R \& D$ investments, and we discuss it below.

The first component of $k_{i t}^{I}$ captures the portion of the stock of intangibles capital that is the result of investment in intangibles assets that are capitalized. For a drug company (e.g. Merck) or a tech company (e.g. Cisco) this component will contain balance sheet items such as "Goodwill" and/or "Intangibles Assets".

The second component of $k_{i t}^{I}$ is an attempt to capture the portion of the stock of intangibles capital that is the result of $R \& D$ investments. Our component is essentially a cumulative sum of all past R\&D expenses, adjusted for depreciation. We assume a depreciation rate, $\delta^{I}$, of $10 \%$, which corresponds to an amortizable life - the length of time it takes research and development investments to be converted into commercial products - for R\&D investments of 10 years. To put this number in perspective, it takes about 10 years for a drug company to get approval for a new drug from the Food and Drugs Administration. ${ }^{10} \mathrm{We}$ have experimented with various values for $\delta^{I}$, ranging from $0 \%$ to $20 \%$, and our results are qualitatively unchanged. These additional results are available upon request.

We define investment in intangible assets as the percentage change in $k_{i t}^{I}$ and we denote it with Intan $i t$. We choose to work with investment net of depreciation rather than simply investment to economize on the assumptions about depreciation rates for intangible assets. Recall that we had to make an assumption about the depreciation rate, $\delta^{I}$, of intangible assets that are acquired with research and development expenses. However, it doesn't necessarily follow that intangible assets acquired with capitalized investments depreciate

\footnotetext{
${ }^{10}$ See Damodaran (2009) for more on the amortizable life of research and development.
} 
at the same rate. In fact, one would have to make an assumption about the depreciation rate of intangible assets acquired with capitalized investments, because we only observe the stock of these type of intangible assets.

Now that we have a good measure of intangibles investment, we are ready to explore empirically the relationship between intangible investment and cash flow uncertainty. We employ the same methods and specifications as in the previous section. Specifically, we estimate the models (18) and (19), where we now set $y_{i t}$ to equal $\operatorname{Intan}_{i t}$.

Table III reports the results. The recurring theme across all model specifications, I - VI, is that the empirical relationship between investment in intangible assets and cash flow uncertainty, $\sigma_{i t}$, is strong and negative. In particular, this relationship is robust to time fixed effects and to dynamic panel estimation methods. Interestingly, the relationship between investment in intangible assets and the GDP growth, $g_{t}^{G D P}$, is only positive and statistically significant in only two of our specifications. This suggests that like investment in tangible assets, investment in intangible assets is weaker when cash flow uncertainty is elevated. However, unlike investment in tangible assets, investment in intangible assets is not necessarily stronger when the economy expands ( $g^{G D P}$ is high).

To gauge the economic impact of the empirical relationship between investment in intangible assets and cash flow uncertainty, we perform a similar exercise as with investment in tangible assets. Suppose that the average cash flow uncertainty were to drop from the post-crises level in 2009 to a pre-crises level, such as 2005. Then the average corporate investment in intangible assets would increase by $1.86 \% .^{11}$

\section{Corporate employment}

Our measure of intangible capital stock accounts for many types of intangible assets, but not all of them. One of the most important sources of intangible capital that our measure completely omits is human capital.

Capitalizing human capital is no easy task as investments in human capital are not only expensed but also commingled with other sources of cost of goods sold and operating expenses. While measuring the stock of human capital is of paramount importance in the typical macroeconomic paradigm, we do not attempt to back out such a measure in this paper. Rather, we are mostly interested in understanding how cash flow uncertainty affects the degree to which firms adjust their stock of human capital. Thus our focus is to construct a measure of investment in human capital that captures the sensitivity of changes in human capital stock to uncertainty.

\footnotetext{
${ }^{11}$ Based on the times series of cross-sectional averages of investment and uncertainty measures in Figure 3 and 1, we notice that between 2005 and 2009 average investment in intangible assets dropped from 10.04\% to $3.81 \%$, while average $\sigma$ increased from $2.76 \%$ to $4.36 \%$. Thus, if $\sigma$ were to drop to the 2005 level, investment would increase by $-1.165 \times(2.76 \%-4.36 \%)=1.86 \%$.
} 
One such measure that is likely to be highly correlated with the unobserved human capital investment is employment change. This measure is simply the annual rate of change in the number of employees in a firm (change in number of employees from past year divided by the past year number of employees), and we denote it with $E m p_{i t}$. While this measure is arguably subject to potential problems (e.g. How accurately do firms report the current number of employees on payroll etc), the one clear advantage of using this measure is the fact that data on the number of employees is available at firm level. Most importantly for our goal, this measure is likely to capture one of the most important stylized facts around economic recessions/expansions: firms reduce labor investment during economic recessions and increase labor investment during economic expansion. ${ }^{12}$ Figure ?? displays this behavior at the aggregate level as well as industry level.

In this section we use employment change to analyze the extend to which firms adjust labor demand in response to innovations in cash flow uncertainty. We employ the same methods and specifications as in the previous two sections. Specifically, we estimate the models (18) and (19), where we now set $y_{i t}$ to equal $\mathrm{Emp}_{i t}$. We report the results in Tables IV.

Our findings support overwhelmingly a strong negative relationship between employment change and cash flow uncertainty. This relationship is robust to time fixed effects as well as estimation methodology. Incidentally we notice that while the estimates for the strength of this relationship are particularly sensitive to time fixed effects, these estimates from the specifications with time dummies are still statistically significant. We also notice that the relationship between employment change and GDP growth rate is strong and positive only in specifications without time-fixed effects. These results suggest that like investment in tangible or intangible assets, corporate employment change declines as a result of an increase in cash flow uncertainty. However, unlike investment in tangible assets, corporate employment change does not necessarily increase as a result of and increase in the GDP growth rate.

Just as in the previous two sections, we can gauge the economic impact of the empirical relationship between employment change and cash flow uncertainty with the following exercise. Suppose that average cash flow uncertainty were to drop from the post-crises level in 2009 to a pre-crises level, such as 2005. Then the average corporate employment change would increase by $1.87 \% .{ }^{13}$ We can further recast this percentage improvement in employment change in terms of number of jobs. Average aggregate employment in the U.S. in 2008 was 130 million, while average employment change across firms was $-2.59 \% .{ }^{14}$ Relative to 2009 , a drop in cash flow uncertainty to the 2005 level would add

\footnotetext{
${ }^{12}$ See for instance Boileau and Normandin (2002), Reinhart and Rogoff (2009), IMF (2010), and Verick (2009).

${ }^{13}$ Based on the times series of cross-sectional averages of employment change and uncertainty measures in Figure 3 and 1, we notice that between 2005 and 2009 average employment change across firms dropped from $5.58 \%$ to $-2.59 \%$, while average $\sigma_{i t}$ increased from $2.76 \%$ to $4.36 \%$. Thus, if $\sigma_{i t}$ were to drop to the 2005 level, employment change would increase by $-1.171 \times(2.76 \%-4.36 \%)=1.87 \%$.

${ }^{14}$ According to the historical establishment data (Table B-1) made available by the Bureau of Labor Statis-
} 
2.43 million jobs to the economy. ${ }^{15}$ These are large magnitudes, suggesting that firms adjust swiftly their use of labor to counteract the negative impact of large innovations in cash flow uncertainty.

\section{The financial crisis of 2007-2008}

In this section we ask whether the strength of the relationships between cash flow uncertainty and corporate investment and employment changes with the state of the economy. A casual look at the time variation of our measure of cash flow uncertainty in Figure 3 reveals that $\sigma_{i t}$ is substantially more elevated during the late financial crises than prior to the crises. This leaves open the possibility that the relationships between cash flow uncertainty and corporate investment and employment can be different across different states of the economy. To test whether this is indeed the case, we estimate the strength of these relationships from two different periods surrounding the late financial crises, namely 2004-2007, and 2008-2011.

We use each of the three econometric models proposed before, namely the fixed-effects panel model (18) and the dynamic panel models (19), with either endogenous or exogenous assumptions about $\sigma_{i t}$. To facilitate the comparison of the estimated coefficients across the two periods, we normalized the cash flow uncertainty measures (interacted with a dummy variable indicating the period), $\sigma_{i t} 1_{\{04-07\}}$ and $\sigma_{i t} 1_{\{08-11\}}$ to have unit standard deviation. We denote the normalized cash flow measures across the two periods with $\bar{\sigma}_{i t} 1_{\{04-07\}}$ and $\bar{\sigma}_{i t} 1_{\{08-11\}}$, respectively. Table $\mathrm{V}$ summarizes the results from each econometric model for either type of corporate investment and for corporate employment.

Regardless of the econometric model used, the results confirm that the relationships between cash flow uncertainty and corporate investment and employment are strong and negative in both the pre-crises and post-crises periods. However, the results also underline a novel and interesting pattern. Namely, that both corporate investment and employment are more sensitive to changes in the cash flow uncertainty measure in the post-crises period rather than in the pre-crises period. The formal test of whether the slope coefficients are indeed different across the two periods rejects the null in most specifications. These results suggest that the strength of the relationships between cash flow uncertainty and corporate investment and employment depend indeed on the state of the economy. In particular, any corporate and government policy directed toward reducing cash flow uncertainty in order to stimulate corporate investment/employment should be more effective during time of economic of distress.

tics.

${ }^{15}$ The number of jobs added as a result of the increase in the employment change is simply $2.43=1.87 \% \times$ 130 million jobs. 


\section{Robustness}

In this section we explore the robustness of our results to changes in the econometric model specifications. In particular, we want to understand whether the main results are robust to the choice of projecting variables for constructing the cash flow uncertainty measure $\sigma_{i t}$, the process of constructing the stock of intangible assets, the linear assumption in the panel data models, and the sample size.

We start we the choice of projecting variables. An important step in constructing $\sigma_{i t}$ is identifying conditional variables that could be informative about the conditional variance of cash flow uncertainty. We use the volatility index $V I X$ as our sole projection variable. An alternative to VIX is the policy uncertainty index proposed by Baker, Bloom, and Davis (2011). This index captures three aspects of policy uncertainty, namely the frequency of references to policy-related economic uncertainty in the Google-media catalog, the number of tax measures set to expire in future years, and finally, the dispersion among economic forecasters about government spending and CPI price level.

We replace VIX with this policy uncertainty index and construct a new uncertainty measure using the same exact methodology as we used in constructing $\sigma_{i t}$. We denote the new uncertainty measure with $\sigma_{i t}^{B B D}$. Figure 4 plots the time-varying component and the firm-specific components of $\sigma_{i t}^{B B D}$. Notice that there is tremendous variation over time in the cross-sectional distribution of firm-specific components. In particular, when combining the time-varying component with the time-varying distribution of the firm-specific component we obtain that the time series of the average levels of $\sigma_{i t}^{B B D}$ can depart substantially from the time-series of the levels of the time-varying component alone (which is based on BBD's policy uncertainty index).

Next we then re-estimate the empirical relationships between corporate investment/employment and $\sigma_{i t}^{B B D}$ using the econometrics models (18) and (19). We consider the same specifications of these models as the ones in Section IV, Tables II - IV. We find that when cash flow uncertainty is measured using $\sigma_{i t}^{B B D}$, the relationships between corporate investment/employment and cash flow uncertainty is still negative and statistically significant. To illustrate, Table VI reports the estimates of the dynamic panel-data model (19) for corporate investment in both tangible and intangible assets as well as corporate employment. In each instance of the model and regardless of whether time dummies are present or not, the coefficient in front of $\sigma_{i t}^{B B D}$ is always negative and statistically significant.

To gauge the economic impact of the negative relationships between corporate investment/employment and $\sigma_{i t}^{B B D}$, we use the same hypothetical exercise that we perform in Section IV. Namely, we compute the change in either corporate investment or corporate employment as a result of a change in the average level of $\sigma_{i t}^{B B D}$ from the post-crisis level of 2009 to a pre-crisis level, such as 2005, 2000, 1995, or 1990. Table ?? presents the results. For ease of comparison we also show the results when the cash flow uncertainty is measured using $\sigma_{i t}$. We notice that the numbers that we obtain are consistent across the two panels when the comparison year are 2005, 1995, or 1990, but not so much when the 
comparison year is 2000 . This is because the BBD index is relatively low during the technology boom period (1995-2000), while the VIX is relatively elevated during the same period (the correlation coefficient between VIX and BBD's the policy uncertainty index is only 0.4 ).

We also consider two other candidates for the projecting variables used in constructing $\sigma_{i t}$, namely the news component of the BBD index and the industry-level equity return volatility. The latter is computed from the equity return times series of the Fama-French industry portfolios. In both cases we obtain strong and negative relationships between corporate investment/employment and cash flow uncertainty. These results are not reported but available upon request.

Next we turn to the construction of the stock of intangible capital. When measuring investment in intangible assets we use proxy for the capitalized and expensed components of the stock of intangible capital. For instance, in (20) we proxy for the capitalized component with $\mathrm{TA}_{t}-\mathrm{CA}_{t}-\mathrm{PPENT}_{t}$. This measure is certainly highly correlated with the stock of capitalized intangible assets, but it is also contaminated by other type of assets such as financial assets (e.g. commodity futures positions etc). To address this potential issue, we consider also an alternative measure of capitalized tangible assets which picks up more carefully these type of intangible assets. This measure is the variable INTAN in Compustat. According to the Compustat definition this variable accounts for certain types of intangible assets which are capitalized when acquired. Some of these intangible assets include patents, client lists, etc. One problem with this variable is that it is available only from year 2000 onwards.

For the expensed component of intangible capital stock, in (20) we cumulate historical $\mathrm{R} \& \mathrm{D}$ expenses using a depreciation rate of $10 \%$. While our R\&D depreciation rate is somewhat justified by the amortizable life of $R \& D$ capital in industries such as drugs, this number is still ad-hoc. To address this issue we experiment with depreciation rates ranging from $0 \%$ to $20 \%$.

We find that our main results are robust to using these alternative measures for the capitalized and expensed components of intangible capital. These results are not reported in here but are available upon request.

A common specification assumption across our econometric panel data models is their linearity in the explanatory variables. This assumption is not necessarily consistent with the investment dynamics in many models of the firm, including our model in Section II. For instance, in our model, optimal investment in equation (11) depends on the marginal $q$ in a very non-linear fashion. In our econometric specification we use Tobin's $\mathrm{Q}$ as a proxy for marginal $q$, and we assume that Tobin's $\mathrm{Q}$ affects linearly corporate investment or employment. To test for the possibility that the interaction between marginal $q$ and corporate investment/employment is non-linear we replace Tobin's $Q$ with two variables that are nonlinear in Tobin's Q, namely the square root of Tobin's Q and the inverse of the square-root of Tobin's Q. We have also considered other power coefficients either 
above or below 1. In all cases, we obtain that even when we account for a potentially non-linear relationship between investment/employment and Tobin's Q, the relationship between corporate investment/employment and cash flow uncertainty is still negative and strongly significant.

In the process of constructing our measure of uncertainty $\sigma_{i t}$ we typically exclude outlier observations (bottom 1\% or top 99\%). It is possible that these observations are themselves informative to some degree. To address this issue we construct a rank-based measure of cash flow uncertainty and re-run the tests using this new measure instead of $\sigma_{i t}$. We find that the results do not change significantly.

Finally, our results are robust to different sample periods. In particular, the negative relationships between corporate investment /employment and cash flow uncertainty is present in the sample period 1987-1999 as well as 2000-2011. These results are not reported in the paper but are available upon request.

\section{Discussion and Conclusions}

An important stylized fact of the U.S. aggregate corporate activity is that corporate investment declines rapidly in the period leading to an economic recession, but rebounds equally rapidly in the period following a recession. For instance, Figure 3 shows that corporate investment reached pre-recession levels within 2-3 years following the recessions of 1991 and 2001.

However, the late financial crisis of 2007-2008 challenged this stylized empirical fact, as corporate investment post-recession grew painfully slow and failed to rebound to prerecession levels. This observation has puzzled economist and policy makers alike because it is not immediately clear what causes the delay in corporate investment. For instance, a typical bottleneck known to preclude firms from pursuing growth opportunities is access to capital. However, in the aftermath of the 2008 financial crisis, the efforts of policy makers to resuscitate the credit channel failed to jump start corporate investment. Kahle and Stulz (2010) show that post-recession firms do not behave as if they face higher cost of capital. Quite the opposite in fact, as many firms hold on to significant amounts of cash on their balance sheet. This begs the obvious question: If firms face relatively unchanged or even lower costs of capital, why do we see so little corporate investment?

In this paper we argue that firms could chose to forego investment opportunities if firms assign larger conditional variances to future cash flows and, as a result, the marginal q of their investment opportunities declines.

Our argument is rooted in a theoretical framework, but crystalized by the empirical tests on the U.S. corporate date.

We construct a measure of cash flow uncertainty and show that this measure is strongly negatively related to corporate investment in tangible and intangible assets as well as 
corporate investment. Furthermore, the impact of the cash flow uncertainty on corporate investment and employment activity is significantly stronger during the post-crisis period of 2008-2011 than during the pre-crisis period of 2004-2007 leading up to the crisis.

These findings have significant policy implications. To wit, if policy makers would like corporations to increase their investment activity, they should focus on policies that decrease corporate cash flow uncertainty. Specifically, to the extent corporations are uncertain about the implementation and the implementation-timeline of the health reform act, and the impact of this act on their costs of hiring and retaining employees - a clarification of the implementation and the implementation-timeline of the health reform act would encourage corporations to invest more and hire more employees. Similarly, to the extent corporations are uncertain about the implementation and the implementation-timeline of the environmental cap-and-trade reform and corporate tax reforms - a clarification of the implementation and the implementation-timeline of these environmental and tax reforms would encourage corporations to invest more and hire more employees. 


\section{Appendix}

Substituting the optimal demand for labor and the wages back into the definition of firm cash flows we obtain

$$
\pi_{t}=\alpha \frac{1-\tau}{1-\alpha} w_{t}^{\frac{1+\theta}{\theta}}+\rho k_{t} .
$$

Writing this equation for $t+1$ and using the optimal investment rule and the capital dynamics gives the dynamics of firm cash flows in the text, where the function $H$ is defined as follows

$$
H\left(w_{t}, p_{t}\right)=\left[\rho \frac{\theta}{\theta+1}+\alpha \frac{1-\tau}{1-\alpha}\right] w_{t}^{\frac{\theta}{1+\theta}}-\rho(1-\tau)(1-\alpha)^{-\frac{1}{\alpha}} w_{t}^{\nu} p_{t}^{-\frac{1}{\alpha}} .
$$

To obtain the dynamics of the shadow cost of capital, $q_{t}$, we first notice that one can obtain an equivalent way of characterizing the first order condition of the investment decision by substituting directly the capital dynamic equation in the investors/consumers utility function and then taking the first derivative with respect to $x_{t}$. This yields

$$
u_{1}\left(c_{t}, l_{t}^{S}\right)=\beta E_{t}\left[v^{\prime}\left(\pi_{t+1}\right) \frac{\partial \pi_{t+1}}{\partial x_{t}}\right]
$$

where $v$ is the indirect utility of the investors/consumers. We now substitute in this equation the Envelope condition

$$
v^{\prime}\left(\pi_{t}\right) \frac{\partial \pi_{t}}{\partial k_{t}}=\frac{\partial \pi_{t}}{\partial k_{t}}\left\{q_{t}-(1-\delta)\right\}
$$

after noticing that $\frac{\partial \pi_{t+1}}{\partial k_{t+1}}=\frac{\partial \pi_{t+1}}{\partial x_{t}}$ and obtain the dynamics of $q_{t}$ in the text, where the function $G$ is defined as follows

$$
G\left(w_{t+1}, p_{t+1}, \epsilon_{t+1}\right)=(1-\tau) \alpha(1-\alpha)^{\frac{1-\alpha}{\alpha}}\left[A p_{t+1}\right]^{\frac{1}{\alpha}} w_{t+1}^{1-\frac{1}{\alpha}}+\rho-(1-\delta)-\epsilon_{t+1} .
$$




\section{References}

Abel, A., 1983, Optimal investment under uncertainty, American Economic Review 73, 228-33.

— 1984, The effects of uncertainty on investment and the expected long-run capital stock, Journal of Economic Dynamic and Control 7, 39-54.

- 1985, A stochastic model of investment marginal $q$ and the market value of the firm, International Economic Review 26, 305-22.

Ahn, S.C., and P. Schmidt, 1995, Efficient estimation of models for dynamic panel data, Journal of Econometrics 68, 5-27.

Anderson, C., and L. Garcia-Feijoo, 2006, Empirical evidence on capital investment, growth opportunities, and security returns, Journal of Finance 61, 171-194.

Arellano, M., and S. Bond, 1992, Some tests of specification for panel data: Monte carlo evidence and an application to employment equations, The Review of Economic Studies 58, 277-297.

Arellano, M., and O. Bover, 1995, Another look at the instrumental variable estimation of error-component models, Journal of Econometrics 68, 29-51.

Baker, S.C., N. Bloom, and S. Davis, 2011, Measuring economic policy uncertainty, Working Paper.

Bhagat, S., and I. Welch, 1995, Corporate research and development investments: international comparisons, Journal of Accounting and Economics 19, 140-146.

Bloom, N., 2009, The impact of uncertainty shocks, Econometrica 77, 623-685.

- S. Bond, and J. van Reenen, 2007, Uncertainty and investment dynamics, The Review of Economic Studies 74, 391-415.

Blundell, R., S. Bond, M. Devereux, and F. Schiantarelli, 1992, Investment and tobin's q, Journal of Econometrics 51, 233-257.

Boileau, M., and M. Normandin, 2002, Aggregate employment, real business cylces, and superior information, Journal of Monetary Economics 49, 495-520.

Bulan, L., 2005, Real options, irreversible investment and firm uncertainty: New evidence from u.s. firms, Review of Financial Economics 14, 255-279.

Caballero, R., 1991, On the sign of the investment-uncertainty relationship, American Economic Review 81, 279-288. 
Cooper, M., H. Gulen, and M. Schill, 2008, Asset growth and the cross-section of stock returns, Journal of Finance Forthcoming.

Damodaran, A., 2009, Valuing companies with intangible assets, Working Paper, New York University, Stern School of Business.

Dixit, A., and R. Pindyck, 1994, Investment under uncertainty, Princeton University Press, Princeton, NJ.

Duchin, R., O. Ozbas, and B.A. Sensoy, 2010, Costly external finance, corporate investment, and the subprime mortgage credit crisis, Journal of Financial Economics 97, $418-435$.

Fazzari, S., R. Hubbard, and B. Petersen, 1998, Finance constraints and corporate investment, Brooking Papers on Economic Activity 1, 141-195.

Fee, E., C. Hadlock, and J. Pierce, 2009, Investment, financing constraints, and internal capital markets: evidence from advertising expenditures of multinational firms, The Review of Financial Studies 22, 2361-2392.

Gilchrist, S., and C. Himmelberg, 1999, Investment: Fundamentals and finance, Chapter (p.223-274) in NBER Macroeconomics Annual 1998, Vol 13 edited by B.S. Bernanke and J. Rotemberg, MIT Press.

Hall, R., 2001, The stock market and capital accumulation, American Economic Review 91, 1185-1202.

Hartman, R., 1972, The effect of price and cost uncertainty on investment, Journal of Economic Theory 5, 258-266.

Hayashi, F., and T. Inoue, 1991, The relation between firm growth and q with multiple capital goods: Theory and evidence, Econometrica 59, 731-753.

IMF, 2010, Output and unemployment dynamics during the great recession: A panel unobserved component analysis, IMF Working Paper 10/185.

Kahle, K., and R. Stulz, 2010, Financial policies and the financial crisis: How important was the systemic credit contraction for industrial corporations?, Working paper, Ohio State University, Fisher College of Business.

Kaplan, S., and L. Zingales, 1997, Do investment-cash flow sensitivities provide useful measures of financing constraints?, Quarterly Journal of Economics 112, 169-215.

King, R.G., and S.T. Rebelo, 2000, Resuscitating real businesscycles, NBER Working Paper No. 7534.

Leahy, J., and T. Whited, 1996, The effect of uncertainty on investment: Some stylized facts, Journal of Money, Credit and Banking 28, 64-83. 
McDonald, R., and D. Siegel, 1985, Investment and the valueation of firms when there is an option to shut down, International Economic Review 26, 331-349.

, 1986, The value of waiting to invest, Quarterly Journal of Economics 101, 707727

McGrattan, E., and E. Prescott, 2005a, Productivity and the post-1990 u.s. economy, Federal Bank of St. Louis Review 87, 537-49.

- 2005b, Taxes, regulation, and the value of u.s. and u.k. corporations, The Review of Economic Studies 72, 767-796.

Panousi, V., and D. Papanikolaou, 2010, Investment, idiosyncratic risk, and ownership, Working paper, Northwestern University.

Pindyck, R., 1988, Irreversible investment, capacity choice, and the value of the firm, American Economic Review 78, 969-85.

Reinhart, C., and K. Rogoff, 2009, The aftermath of financial crises, NBER Working Paper No. w14656.

Saltari, E., and D. Ticchi, 2007, Risk aversion, intertemporal substitution, and the aggregate investment-uncertainty relationship, Journal of Monetary Economics 54, 622648.

Shaanan, J., 2005, Investment, irreversibility, and options: An empirical framework, $R e$ view of Financial Economics 14, 241-254.

Verick, S., 2009, Who is hit hardest during a financial crisis? the vulnerability of young men and womento unemployment in an economic downturn, ILO Discussion Paper.

Whited, T., and G. Wu, 2006, Financial constraints risk, The Review of Financial Studies $19,531-539$. 


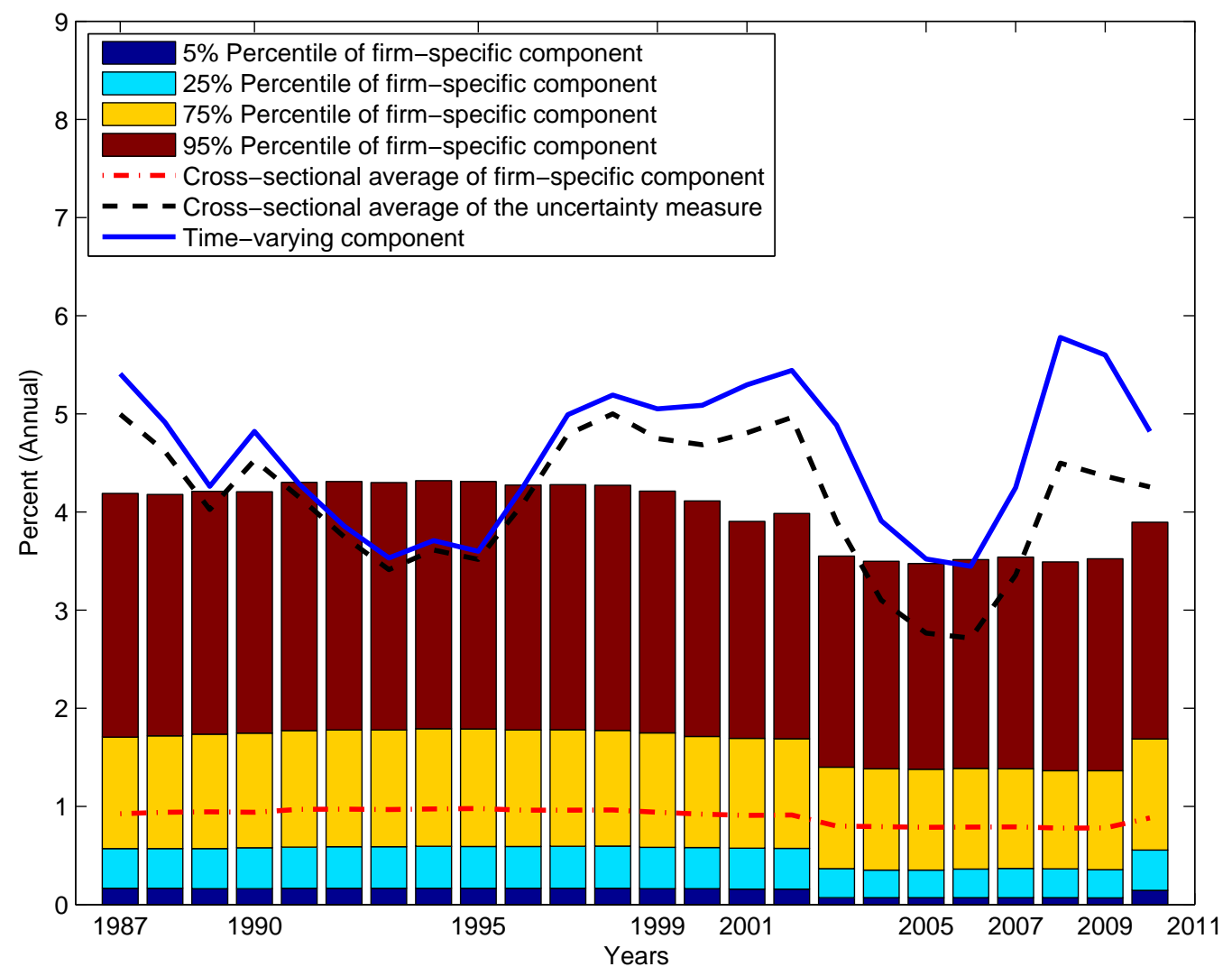

Figure 1: Cash flow uncertainty measure: For each firm we estimate the cash flow uncertainty measure $\sigma_{i t}$ as described in equation (17). This measure is the product of a time-invariant firm-specific component, $\sqrt{\eta_{i}}$, and a firm-independent time-varying component, $\sqrt{V I X} t$. The vertical bars in the plot show the distribution $(5 \%, 25 \%, 75 \%$, and $95 \%$ percentiles) of the firm-specific component over time. The dotted line between the 25 and 75-percentiles is the cross-sectional average of these firm-specific components. The continuous line shows the time-varying component, $\sqrt{V I X}$, divided by 100 . Finally, the dashed line shows the cross-sectional average of $\sigma_{i t}$ (the product of the cross-sectional average of the firm-specific component and the time-varying component $\sqrt{V I X} t)$. 


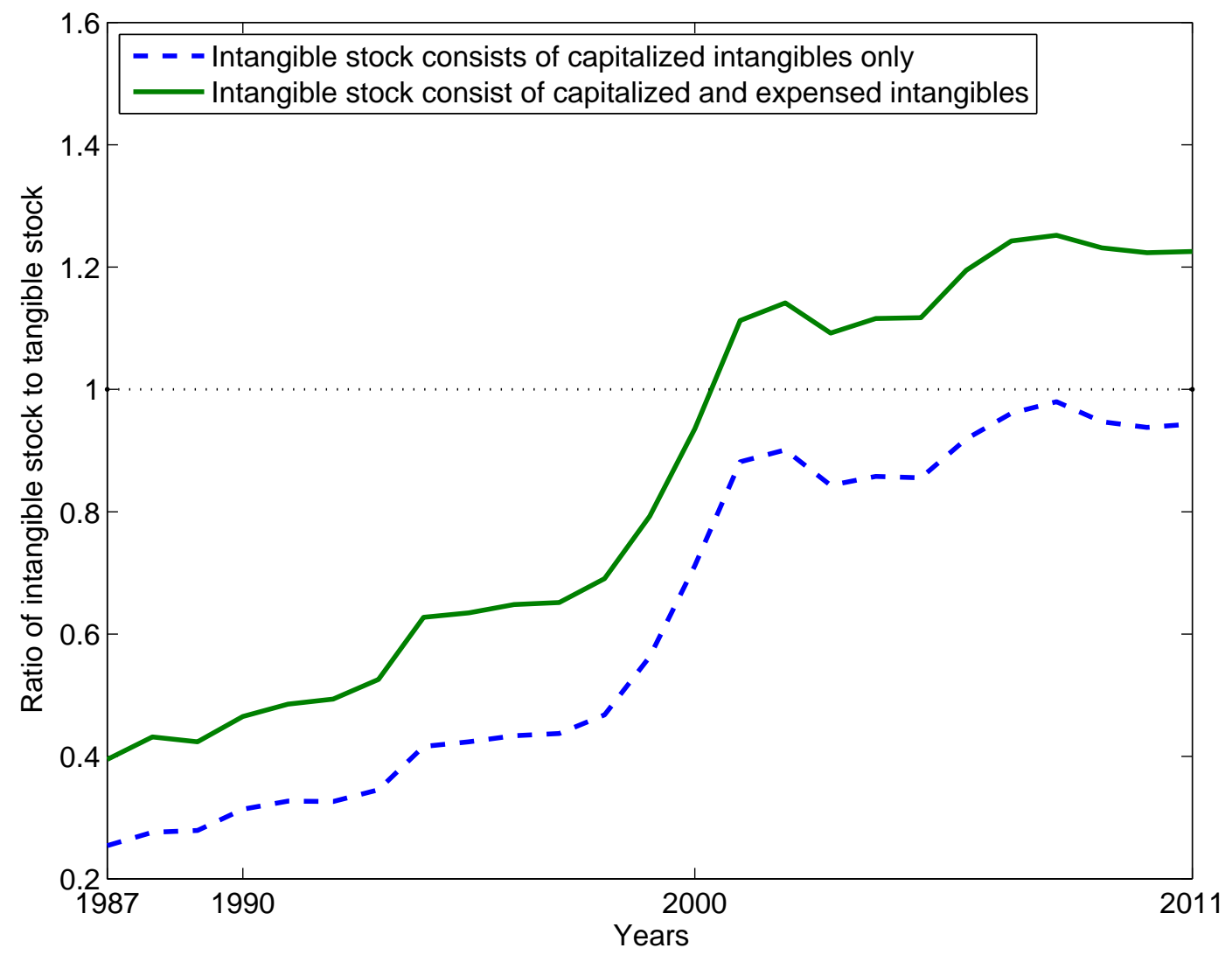

Figure 2: Stock of intangible capital: This figure plots the ratio of cross-sectional median of intangible capital stock and cross-sectional median of tangible capital stock. The stock of capitalized intangible capital is measured as book assets minus current assets, minus net property, plant and equipment. The stock of capitalized+expensed intangible capital is measured as book assets minus current assets, minus net property, plant and equipment, and plus the sum of current and past R\&D expenses, $\sum_{s=t-T}^{t}(1-10 \%)^{t-s} R \& D_{s}$, adjusted for a $10 \%$ annual depreciation. The stock of tangible capital is measured as net plant, property and equipment. 


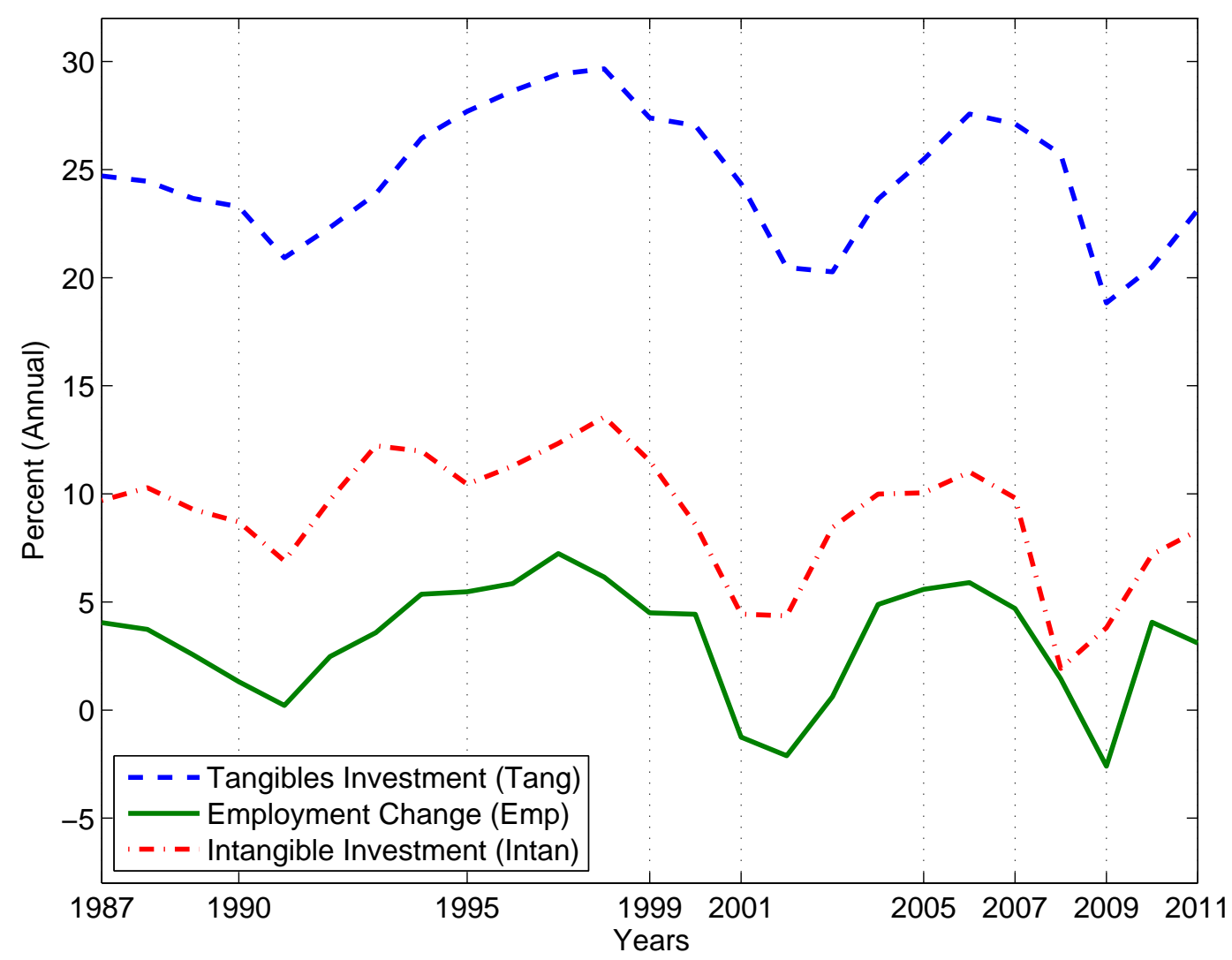

Figure 3: Corporate investment and employment: The plot shows the cross-sectional averages of employment change, Emp $p_{i t}$, corporate investment in tangible assets, $\mathrm{Tang}_{i t}$, and corporate investment in intangible assets, Intan $i t$, over time. All time-series are normalized by their time-series median levels. 
Sample statistics (1987-2011)

\begin{tabular}{|c|c|c|c|c|c|c|c|c|c|}
\hline Statistic & $\operatorname{Tang}_{i(t+1)}$ & $\operatorname{Intan}_{i(t+1)}$ & $E m p_{i(t+1)}$ & $g_{t}^{G D P}$ & $\sigma_{i t}$ & $\mathrm{MA}_{i t} / \mathrm{BA}_{i t}$ & $\mathrm{CF}_{i t} / \mathrm{K}_{i(t-1)}$ & $\mathrm{Ca}_{i t} / \mathrm{BA}_{i t}$ & $\mathrm{BD}_{i t} / \mathrm{BA}_{i}$ \\
\hline Mean & 0.2242 & 0.1043 & 0.0506 & 0.0000 & 0.0409 & 1.6339 & 0.5552 & 0.9505 & $\overline{0.1991}$ \\
\hline Median & 0.1769 & 0.0791 & 0.0170 & 0.0269 & 0.0309 & 1.2948 & 0.3172 & 0.1870 & 0.1807 \\
\hline St dev & 0.1737 & 0.2941 & 0.2094 & 0.1177 & 0.0397 & 1.1079 & 1.0457 & 2.1294 & 0.1637 \\
\hline Min & -0.3561 & -0.9999 & -0.9998 & -0.6206 & 0.0002 & 0.2146 & -50.2491 & 0.0000 & 0.0000 \\
\hline $1 \%$ & 0.0062 & -0.7604 & -0.4408 & -0.5705 & 0.0020 & 0.6295 & -0.7426 & 0.0005 & 0.0000 \\
\hline $25 \%$ & 0.1029 & -0.0341 & -0.0380 & 0.0165 & 0.0170 & 1.0528 & 0.1455 & 0.0429 & 0.0545 \\
\hline $75 \%$ & 0.2920 & 0.2405 & 0.1020 & 0.0407 & 0.0515 & 1.8115 & 0.6550 & 0.8072 & 0.3058 \\
\hline $99 \%$ & 0.8437 & 0.9111 & 0.8958 & 0.0889 & 0.2146 & 6.1641 & 4.7248 & 11.6453 & 0.6621 \\
\hline Max & 0.9983 & 0.9999 & 1.4892 & 0.4159 & 0.6547 & 24.9554 & 9.9999 & 19.9683 & 0.9510 \\
\hline \multicolumn{10}{|c|}{ Sample correlation coefficients (1987-2011) } \\
\hline Variable & $\operatorname{Tang}_{i(t+1)}$ & $\operatorname{Intan}_{i(t+1)}$ & $E m p_{i(t+1)}$ & $g_{t}^{G D P}$ & $\sigma_{i t}$ & $\mathrm{MA}_{i t} / \mathrm{BA}_{i t}$ & $\mathrm{CF}_{i t} / \mathrm{K}_{i(t-1)}$ & $\mathrm{Ca}_{i t} / \mathrm{BA}_{i t}$ & $\overline{\mathrm{BD}}_{i t} / \mathrm{BA}_{i}$ \\
\hline $\operatorname{Tang}_{i(t+1)}$ & 1.0000 & & & & & & & & \\
\hline $\operatorname{Intan}_{i(t+1)}$ & 0.1468 & 1.0000 & & & & & & & \\
\hline$E m p_{i(t+1)}$ & 0.2937 & 0.2480 & 1.0000 & & & & & & \\
\hline$g_{t}^{G D P}$ & 0.1169 & 0.0559 & 0.0797 & 1.0000 & & & & & \\
\hline$\sigma_{i t}$ & 0.1257 & -0.0023 & -0.0064 & -0.0034 & 1.0000 & & & & \\
\hline $\mathrm{MA}_{i t} / \mathrm{BA}_{i t}$ & 0.2921 & 0.1656 & 0.1665 & 0.0734 & 0.2093 & 1.0000 & & & \\
\hline $\mathrm{CF}_{i t} / \mathrm{K}_{i(t-1)}$ & 0.3569 & 0.1126 & 0.1226 & 0.0296 & 0.1314 & 0.3253 & 1.0000 & & \\
\hline $\mathrm{Ca}_{i t} / \mathrm{BA}_{i t}$ & 0.3000 & 0.0962 & 0.0738 & 0.0208 & 0.1091 & 0.2195 & 0.5689 & 1.0000 & \\
\hline $\mathrm{BD}_{i t} / \mathrm{BA}_{i t}$ & -0.2867 & -0.1420 & -0.0829 & 0.0218 & -0.1780 & -0.2703 & -0.2725 & -0.2993 & 1.0000 \\
\hline
\end{tabular}

Table I: This table reports sample statistics and correlation coefficients between variables used in our empirical analysis. Tang $g_{i(t+1)}$ is investment in tangible assets and is measured as the ratio of capital expenditures at time $t+1$ to capital stock at time $t$. Intan $i(t+1)$ is investment in intangible assets and is measured as the ratio of the change in the stock of intangible capital between $t$ and $t+1$ to the stock of intangible capital at time $t$. The construction of the stock of intangible capital is described in Section IV.A. $E m p_{i(t+1)}$ is employment change is measured as the ratio of the change in the number of employees between $t$ and $t+1$ to the number of employees at time $t . g_{t}^{G D P}$ is the annual real GDP growth, $\sigma_{i t}$ is our measure of cash flow uncertainty, $\mathrm{MA}_{i t} / \mathrm{BA}_{i t}$ is the ratio of market assets to book assets, $\mathrm{Ca}_{i t} / \mathrm{BA}_{i t}$ is the ratio of cash to book assets, $\mathrm{CF}_{i t} / \mathrm{K}_{i(t-1)}$ is the ratio of cash flows to capital stock, and $\mathrm{BD}_{i t} / \mathrm{BA}_{i t}$ is the ratio of book debt to book assets. 
Dependent variable: Tang $_{i(t+1)}=$ Investment in tangible assets between $t$ and $t+1$ Sample period: 1987-2011 using all COMPUSTAT firms

\begin{tabular}{lllllll}
\hline \hline $\begin{array}{l}\text { Independent } \\
\text { variables }\end{array}$ & $\mathrm{I}$ & $\mathrm{II}$ & $\mathrm{III}$ & $\mathrm{IV}$ & $\mathrm{V}$ & $\mathrm{VI}$ \\
\hline Tang & & - & $0.258^{* * *}$ & $0.266^{* * *}$ & $0.263^{* * *}$ & $0.259^{*}$ \\
& - & - & $(16.83)$ & $(17.24)$ & $(17.21)$ & $(2.54)$ \\
$g_{t}^{G D P}$ & $0.676^{* * *}$ & $0.211^{* *}$ & $0.547^{* * *}$ & $0.235^{*}$ & $0.529^{* * *}$ & $0.271^{*}$ \\
& $(10.90)$ & $(2.83)$ & $(9.87)$ & $(2.10)$ & $(9.63)$ & $(2.40)$ \\
$\sigma_{i t}$ & $-0.927^{* * *}$ & $-0.587^{* *}$ & $-0.880^{* * *}$ & $-0.813^{* *}$ & $-0.740^{* * *}$ & $-0.540^{*}$ \\
& $(-6.11)$ & $(-3.23)$ & $(-5.61)$ & $(-2.82)$ & $(-5.59)$ & $(-2.51)$ \\
$\mathrm{MA}_{i t} / \mathrm{BA}_{i t}$ & $0.032^{* * *}$ & $0.031^{* * *}$ & $0.027^{* * *}$ & $0.028^{* * *}$ & $0.029^{* * *}$ & 0.029 \\
& $(8.00)$ & $(7.63)$ & $(5.36)$ & $(5.15)$ & $(5.83)$ & $(1.48)$ \\
$\mathrm{CF}_{i t} / \mathrm{K}_{i(t-1)}$ & $0.034^{* * *}$ & $0.032^{* * *}$ & $0.023^{* * *}$ & $0.026^{* * *}$ & $0.025^{* * *}$ & $0.028^{* * *}$ \\
& $(10.37)$ & $(10.12)$ & $(3.92)$ & $(4.10)$ & $(3.97)$ & $(4.27)$ \\
$\mathrm{Ca}_{i t} / \mathrm{BA}_{i t}$ & $0.007^{* * *}$ & $0.009^{* * *}$ & $0.009^{* * *}$ & $0.011^{* * *}$ & $0.010^{* * *}$ & $0.011^{* *}$ \\
& $(6.90)$ & $(8.45)$ & $(3.40)$ & $(3.60)$ & $(3.52)$ & $(2.82)$ \\
$\mathrm{BD}_{i t} / \mathrm{BA}_{i t}$ & $-0.165^{* * *}$ & $-0.171^{* * *}$ & $-0.135^{* * *}$ & $-0.111^{* *}$ & $-0.140^{* * *}$ & -0.112 \\
& $(-12.47)$ & $(-12.83)$ & $(-3.83)$ & $(-2.90)$ & $(-5.59)$ & $(-0.31)$
\end{tabular}

Sargan test of overidentifying moment restrictions

\begin{tabular}{lllllll}
\hline Test & - & - & $\chi^{2}(1102)$ & $\chi^{2}(887)$ & $\chi^{2}(1048)$ & $\chi^{2}(905)$ \\
Value & - & - & $1222.6^{* *}$ & $990.8^{* *}$ & $1167.0^{* *}$ & $1004.9^{* *}$
\end{tabular}

Tests of joint significance of independent variables

\begin{tabular}{lllllll}
\hline Test & $\mathrm{F}(6,59)$ & $\mathrm{F}(28,59)$ & $\chi^{2}(7)$ & $\chi^{2}(29)$ & $\chi^{2}(7)$ & $\chi^{2}(29)$ \\
Value & $103.0^{* * *}$ & $95.5^{* * *}$ & $965.2^{* * *}$ & $1202.2^{* * *}$ & $1009.4^{* * *}$ & $1097.5^{* * *}$ \\
\hline Time dummies & No & Yes & No & Yes & No & Yes \\
No. Obs. & 25120 & 25120 & 21402 & 21402 & 21402 & 21402 \\
\hline \hline
\end{tabular}

${ }^{*} p<0.05,{ }^{* *} p<0.01,{ }^{* * *} p<0.001$

Table II: This table reports the relationship between investment in tangible assets, Tang $_{i(t+1)}$, measured as the ratio of capital expenditures between $t$ and $t+1$ to capital stock at time $t$, and the cash flow uncertainty measure, $\sigma_{i t}$. Columns I and II report the results from panel-data regressions, with or w/o time-fixed effects. Column III and IV report the results from dynamic panel-data models, with or w/o time dummies, and assume that $\sigma_{i t}$ is exogenous while the rest of the variables are endogenous. Column V and VI report the results from dynamic panel-data models, with or w/o time dummies, and assume that all variables, including $\sigma_{i t}$, are endogenous. All specifications include the following additional explanatory variables: $g_{t}^{G D P}, \mathrm{MA}_{i t} / \mathrm{BA}_{i t}, \mathrm{Ca}_{i t} / \mathrm{BA}_{i t}, \mathrm{CF}_{i t} / \mathrm{K}_{i(t-1)}$, and $\mathrm{BD}_{i t} / \mathrm{BA}_{i t}$. These variables are defined in Table I. In addition, all specifications include firm-fixed effects, and errors are clustered by industry. Reported coefficients are estimated via GMM using the method in Arellano and Bond (1991). For all columns, robust t-statistics are reported in parentheses. 
Dependent variable: $\operatorname{Intan}_{i(t+1)}=$ Investment in intangible assets between $t$ and $t+1$ Sample period: 1987-2011 using all COMPUSTAT firms

\begin{tabular}{|c|c|c|c|c|c|c|}
\hline $\begin{array}{l}\text { Independent } \\
\text { variables }\end{array}$ & I & II & III & IV & $\mathrm{V}$ & VI \\
\hline Intan $_{i t}$ & $\begin{array}{l}- \\
-\end{array}$ & $\begin{array}{l}- \\
-\end{array}$ & $\begin{array}{l}0.075^{* * *} \\
(5.13)\end{array}$ & $\begin{array}{l}0.080^{* *} \\
(5.30)\end{array}$ & $\begin{array}{l}0.077^{* * *} \\
(5.31)\end{array}$ & $\begin{array}{l}0.078^{* * *} \\
(5.26)\end{array}$ \\
\hline$g_{t}^{G D P}$ & $\begin{array}{l}0.557^{* * *} \\
(4.25)\end{array}$ & $\begin{array}{l}-0.237 \\
(-1.66)\end{array}$ & $\begin{array}{l}0.264 \\
(1.76)\end{array}$ & $\begin{array}{l}-0.449 \\
(-1.18)\end{array}$ & $\begin{array}{l}0.301^{*} \\
(1.98)\end{array}$ & $\begin{array}{l}-0.627 \\
(-1.61)\end{array}$ \\
\hline$\sigma_{i t}$ & $\begin{array}{l}-1.268^{* * *} \\
(-4.92)\end{array}$ & $\begin{array}{l}-1.031^{*} \\
(-2.53)\end{array}$ & $\begin{array}{l}-1.165^{* *} \\
(-2.87)\end{array}$ & $\begin{array}{l}-1.625^{* *} \\
(-2.65)\end{array}$ & $\begin{array}{l}-1.141^{* *} \\
(-2.97)\end{array}$ & $\begin{array}{l}-1.047^{*} \\
(-2.04)\end{array}$ \\
\hline $\mathrm{MA}_{i t} / \mathrm{BA}_{i t}$ & $\begin{array}{l}0.028^{* * *} \\
(5.04)\end{array}$ & $\begin{array}{l}0.028^{* * *} \\
(4.82)\end{array}$ & $\begin{array}{l}0.024^{*} \\
(2.39)\end{array}$ & $\begin{array}{l}0.020^{*} \\
(1.96)\end{array}$ & $\begin{array}{l}0.025^{*} \\
(2.53)\end{array}$ & $\begin{array}{l}0.019 \\
(1.84)\end{array}$ \\
\hline $\mathrm{CF}_{i t} / \mathrm{K}_{i(t-1)}$ & $\begin{array}{l}0.012^{* *} \\
(2.90)\end{array}$ & $\begin{array}{l}0.011^{\text {** }} \\
(3.14)\end{array}$ & $\begin{array}{l}-0.032^{*} \\
(-2.13)\end{array}$ & $\begin{array}{l}-0.006 \\
(-0.35)\end{array}$ & $\begin{array}{l}-0.034^{*} \\
(-2.19)\end{array}$ & $\begin{array}{l}0.007 \\
(0.38)\end{array}$ \\
\hline $\mathrm{Ca}_{i t} / \mathrm{BA}_{i t}$ & $\begin{array}{l}0.003 \\
(1.81)\end{array}$ & $\begin{array}{l}0.007^{* * *} \\
(4.79)\end{array}$ & $\begin{array}{l}-0.003 \\
(-0.28)\end{array}$ & $\begin{array}{l}-0.003 \\
(-0.31)\end{array}$ & $\begin{array}{l}-0.000 \\
(-0.31)\end{array}$ & $\begin{array}{l}0.006 \\
(0.52)\end{array}$ \\
\hline $\mathrm{BD}_{i t} / \mathrm{BA}_{i t}$ & $\begin{array}{l}-0.175^{* * *} \\
(-6.01)\end{array}$ & $\begin{array}{l}-0.192^{* * *} \\
(-6.97)\end{array}$ & $\begin{array}{l}0.035 \\
(0.30)\end{array}$ & $\begin{array}{l}-0.001 \\
(-0.01)\end{array}$ & $\begin{array}{l}0.057 \\
(0.51)\end{array}$ & $\begin{array}{l}-0.019 \\
(-0.13)\end{array}$ \\
\hline \multicolumn{7}{|c|}{ Sargan test of overidentifying moment restrictions } \\
\hline Test & - & - & $\chi^{2}(534)$ & $\chi^{2}(463)$ & $\chi^{2}(522)$ & $\chi^{2}(428)$ \\
\hline Value & - & - & $593.8^{*}$ & $521.5^{*}$ & $581.9^{*}$ & $478.6^{*}$ \\
\hline \multicolumn{7}{|c|}{ Test of joint significance of independent variables } \\
\hline Test & $\mathrm{F}(6,59)$ & $\mathrm{F}(27,59)$ & $\chi^{2}(7)$ & $\chi^{2}(26)$ & $\chi^{2}(7)$ & $\chi^{2}(26)$ \\
\hline Value & $33.18^{* * *}$ & $40.28^{* * *}$ & $61.63^{* * *}$ & $120.56^{* * *}$ & $68.2^{* * *}$ & $135.22^{* * *}$ \\
\hline Time dummies & No & Yes & No & Yes & No & Yes \\
\hline No. Obs. & 19348 & 19348 & 14069 & 14069 & 14069 & 14069 \\
\hline
\end{tabular}

Table III: This table reports the relationship between investment in intangible assets, $\operatorname{Intan}_{i(t+1)}$, measured as the ratio of the change in the stock of intangible capital between $t$ and $t+1$ to the stock of intangible capital at time $t$, and the cash flow uncertainty measure, $\sigma_{i t}$. Columns I and II report the results from panel-data regressions, with or w/o time-fixed effects. Column III and IV report the results from dynamic panel-data models, with or w/o time dummies, and assume that $\sigma_{i t}$ is exogenous while the rest of the variables are endogenous. Column V and VI report the results from dynamic paneldata models, with or w/o time dummies, and assume that all variables, including $\sigma_{i t}$, are endogenous. All specifications include the following additional explanatory variables: $g_{t}^{G D P}, \mathrm{MA}_{i t} / \mathrm{BA}_{i t}, \mathrm{Ca}_{i t} / \mathrm{BA}_{i t}, \mathrm{CF}_{i t} / \mathrm{K}_{i(t-1)}$, and $\mathrm{BD}_{i t} / \mathrm{BA}_{i t}$. These variables are defined in Table I. In addition, all specifications include firm-fixed effects, and errors are clustered by industry. Reported coefficients are estimated via GMM using the method in Arellano and Bond (1991). For all columns, robust t-statistics are reported in parentheses. 
Dependent variable: $E m p_{i(t+1)}=$ Growth in number of employees between $t$ and $t+1$ Sample period: 1987-2011 using all COMPUSTAT firms

\begin{tabular}{lllllll}
\hline \hline $\begin{array}{l}\text { Independent } \\
\text { variables }\end{array}$ & $\mathrm{I}$ & $\mathrm{II}$ & $\mathrm{III}$ & $\mathrm{IV}$ & $\mathrm{V}$ & $\mathrm{VI}$ \\
\hline$E m p_{i t}$ & - & - & $0.076^{* * *}$ & $0.072^{* * *}$ & $0.074^{* * *}$ & $0.075^{* * *}$ \\
& - & - & $(5.31)$ & $(5.11)$ & $(5.16)$ & $(5.29)$ \\
$g_{t}^{G D P}$ & $0.713^{* * *}$ & -0.029 & $0.739^{* * *}$ & -0.119 & $0.839^{* * *}$ & -0.156 \\
& $(8.65)$ & $(-0.23)$ & $(7.49)$ & $(-0.51)$ & $(8.71)$ & $(-0.70)$ \\
$\sigma_{i t}$ & $-1.201^{* * *}$ & $-0.967^{* *}$ & $-1.171^{* * *}$ & $-0.738^{*}$ & $-0.994^{* * *}$ & $-0.614^{*}$ \\
& $(-5.61)$ & $(-3.33)$ & $(-5.33)$ & $(-2.29)$ & $(-4.90)$ & $(-2.48)$ \\
$\mathrm{MA}_{i t} / \mathrm{BA}_{i t}$ & $0.028^{* * *}$ & $0.028^{* * *}$ & $0.028^{* * *}$ & 0.005 & $0.024^{* * *}$ & 0.006 \\
& $(6.95)$ & $(6.93)$ & $(3.90)$ & $(0.23)$ & $(3.90)$ & $(0.96)$ \\
$\mathrm{CF}_{i t} / \mathrm{K}_{i(t-1)}$ & $0.016^{* * *}$ & $0.016^{* * *}$ & -0.007 & -0.000 & -0.008 & -0.009 \\
& $(4.67)$ & $(4.58)$ & $(-0.76)$ & $(-0.07)$ & $(-0.89)$ & $(-1.11)$ \\
$\mathrm{Ca}_{i t} / \mathrm{BA}_{i t}$ & 0.002 & $0.004^{*}$ & -0.004 & 0.004 & -0.005 & 0.002 \\
& $(1.09)$ & $(2.24)$ & $(-0.84)$ & $(0.69)$ & $(-0.96)$ & $(0.38)$ \\
$\mathrm{BD}_{i t} / \mathrm{BA}_{i t}$ & $-0.147^{* * *}$ & $-0.153^{* * *}$ & -0.000 & -0.112 & -0.023 & -0.134 \\
& $(-6.62)$ & $(-7.29)$ & $(-0.01)$ & $(-0.51)$ & $(-0.32)$ & $(-1.76)$
\end{tabular}

Sargan test of overidentifying moment restrictions

\begin{tabular}{lllllll}
\hline Test & - & - & $\chi^{2}(723)$ & $\chi^{2}(601)$ & $\chi^{2}(848)$ & $\chi^{2}(611)$ \\
Value & - & - & $820.8^{* *}$ & $659.9^{*}$ & $966.1^{* *}$ & $670.6^{*}$
\end{tabular}

Tests of joint significance of independent variables

\begin{tabular}{lllllll}
\hline Test & $\mathrm{F}(6,59)$ & $\mathrm{F}(27,59)$ & $\chi^{2}(7)$ & $\chi^{2}(28)$ & $\chi^{2}(7)$ & $\chi^{2}(28)$ \\
Value & $46.94^{* * *}$ & $48.15^{* * *}$ & $270.90^{* * *}$ & $424.45^{* * *}$ & $272.9^{* * *}$ & $431.9^{* * *}$ \\
\hline Time dummies & No & Yes & No & Yes & No & Yes \\
No. Obs. & 21828 & 21828 & 18006 & 18006 & 18006 & 18006 \\
\hline \hline
\end{tabular}

${ }^{*} p<0.05,{ }^{* *} p<0.01,{ }^{* * *} p<0.001$

Table IV: This table reports the relationship between employment change, $E m p_{i(t+1)}$, measured as the ratio of the change in the number of employees between $t$ and $t+1$ to the number of employees at time $t$, and the cash flow uncertainty measure, $\sigma_{i t}$. Columns I and II report the results from panel-data regressions, with or w/o time-fixed effects. Column III and IV report the results from dynamic panel-data models, with or w/o time dummies, and assume that $\sigma_{i t}$ is exogenous while the rest of the variables are endogenous. Column $\mathrm{V}$ and VI report the results from dynamic panel-data models, with or w/o time dummies, and assume that all variables, including $\sigma_{i t}$, are endogenous. All specifications include the following additional explanatory variables: $g_{t}^{G D P}, \mathrm{MA}_{i t} / \mathrm{BA}_{i t}, \mathrm{Ca}_{i t} / \mathrm{BA}_{i t}, \mathrm{CF}_{i t} / \mathrm{K}_{i(t-1)}$, and $\mathrm{BD}_{i t} / \mathrm{BA}_{i t}$. These variables are defined in Table I. In addition, all specifications include firm-fixed effects, and errors are clustered by industry. Reported coefficients are estimated via GMM using the method in Arellano and Bond (1991). For all columns, robust t-statistics are reported in parentheses. 


\begin{tabular}{|c|c|c|c|c|c|c|c|c|c|}
\hline \multirow[b]{3}{*}{ Model: } & \multicolumn{9}{|c|}{ Dependent variable $x_{i(t+1)}$} \\
\hline & \multicolumn{3}{|c|}{$\operatorname{Tang}_{i(t+1)}$} & \multicolumn{3}{|c|}{$\operatorname{Intan}_{i(t+1)}$} & \multicolumn{3}{|c|}{$E m p_{i(t+1)}$} \\
\hline & (I) & (II) & (III) & (I) & (II) & (III) & (I) & (II) & (III) \\
\hline$g_{t}^{G D P}$ & $\begin{array}{l}0.431^{* * *} \\
(5.46)\end{array}$ & $\begin{array}{l}0.307^{* *} \\
(2.96)\end{array}$ & $\begin{array}{l}0.334^{* * *} \\
(3.24)\end{array}$ & $\begin{array}{l}-0.049 \\
(-0.22)\end{array}$ & $\begin{array}{l}-0.539 \\
(-1.72)\end{array}$ & $\begin{array}{l}-0.714^{*} \\
(-2.18)\end{array}$ & $\begin{array}{l}0.552^{* * *} \\
(3.61)\end{array}$ & $\begin{array}{l}0.453^{*} \\
(2.54)\end{array}$ & $\begin{array}{l}0.453^{* *} \\
(2.60)\end{array}$ \\
\hline $\bar{\sigma}_{i t} * 1_{\{08-11\}}$ & $\begin{array}{l}-0.050^{* * *} \\
(-3.43)\end{array}$ & $\begin{array}{l}-0.056^{* * *} \\
(-3.98)\end{array}$ & $\begin{array}{l}-0.057^{* * *} \\
(-4.29)\end{array}$ & $\begin{array}{l}-0.160^{* * *} \\
(-4.81)\end{array}$ & $\begin{array}{l}-0.156^{* * *} \\
(-4.00)\end{array}$ & $\begin{array}{l}-0.161^{* * *} \\
(-3.99)\end{array}$ & $\begin{array}{l}-0.090^{* * *} \\
(-4.53)\end{array}$ & $\begin{array}{l}-0.103^{* * *} \\
(-5.04)\end{array}$ & $\begin{array}{l}-0.099^{* * *} \\
(-4.93)\end{array}$ \\
\hline $\bar{\sigma}_{i t} * 1_{\{04-07\}}$ & $\begin{array}{l}-0.038^{* *} \\
(-2.71)\end{array}$ & $\begin{array}{l}-0.043^{* * *} \\
(-3.24)\end{array}$ & $\begin{array}{l}-0.049^{* * *} \\
(-4.04)\end{array}$ & $\begin{array}{l}-0.135^{* * *} \\
(-3.81)\end{array}$ & $\begin{array}{l}-0.126^{* * *} \\
(-3.66)\end{array}$ & $\begin{array}{l}-0.144^{* * *} \\
(-3.88)\end{array}$ & $\begin{array}{l}-0.081^{* * *} \\
(-3.74)\end{array}$ & $\begin{array}{l}-0.087^{* * *} \\
(-4.60)\end{array}$ & $\begin{array}{l}-0.083^{* * *} \\
(-4.36)\end{array}$ \\
\hline $\mathrm{MA}_{i t} / \mathrm{BA}_{i t}$ & $\begin{array}{l}0.040^{* * *} \\
(6.86)\end{array}$ & $\begin{array}{l}0.025 \\
(1.76)\end{array}$ & $\begin{array}{l}0.038^{* *} \\
(2.99)\end{array}$ & $\begin{array}{l}0.038^{*} \\
(2.26)\end{array}$ & $\begin{array}{l}0.077^{*} \\
(2.29)\end{array}$ & $\begin{array}{l}0.105^{* * *} \\
(3.23)\end{array}$ & $\begin{array}{l}0.035^{* * *} \\
(4.58)\end{array}$ & $\begin{array}{l}0.049^{* *} \\
(2.89)\end{array}$ & $\begin{array}{l}0.049^{* *} \\
(2.83)\end{array}$ \\
\hline $\mathrm{CF}_{i t} / \mathrm{K}_{i(t-1)}$ & $\begin{array}{l}0.018^{* * *} \\
(5.61)\end{array}$ & $\begin{array}{l}0.001 \\
(0.16)\end{array}$ & $\begin{array}{l}0.000 \\
(0.09)\end{array}$ & $\begin{array}{l}0.000 \\
(0.06)\end{array}$ & $\begin{array}{l}-0.035 \\
(-1.84)\end{array}$ & $\begin{array}{l}-0.017 \\
(-0.78)\end{array}$ & $\begin{array}{l}0.005 \\
(1.09)\end{array}$ & $\begin{array}{l}-0.014 \\
(-1.80)\end{array}$ & $\begin{array}{l}-0.015 \\
(-1.91)\end{array}$ \\
\hline $\mathrm{Ca}_{i t} / \mathrm{BA}_{i t}$ & $\begin{array}{l}0.013^{* * *} \\
(7.17)\end{array}$ & $\begin{array}{l}0.021^{* * *} \\
(3.32)\end{array}$ & $\begin{array}{l}0.019^{* *} \\
(3.02)\end{array}$ & $\begin{array}{l}0.006 \\
(1.84)\end{array}$ & $\begin{array}{l}0.010 \\
(0.60)\end{array}$ & $\begin{array}{l}0.016 \\
(0.88)\end{array}$ & $\begin{array}{l}0.003 \\
(1.49)\end{array}$ & $\begin{array}{l}0.001 \\
(0.21)\end{array}$ & $\begin{array}{l}0.002 \\
(0.37)\end{array}$ \\
\hline $\mathrm{BD}_{i t} / \mathrm{BA}_{i t}$ & $\begin{array}{l}-0.146^{* * *} \\
(-4.50)\end{array}$ & $\begin{array}{l}-0.415^{\text {*** }} \\
(-3.19)\end{array}$ & $\begin{array}{l}-0.363^{* *} \\
(-2.88)\end{array}$ & $\begin{array}{l}-0.322^{* * *} \\
(-4.21)\end{array}$ & $\begin{array}{l}-0.016 \\
(-0.05)\end{array}$ & $\begin{array}{l}0.152 \\
(0.45)\end{array}$ & $\begin{array}{l}-0.126^{*} \\
(-2.33)\end{array}$ & $\begin{array}{l}-0.229 \\
(-1.29)\end{array}$ & $\begin{array}{l}-0.234 \\
(-1.54)\end{array}$ \\
\hline$x_{i t}$ & - & $\begin{array}{l}0.240^{* * *} \\
(7.10)\end{array}$ & $\begin{array}{l}0.246^{* * *} \\
(7.19)\end{array}$ & $\begin{array}{l}- \\
-\end{array}$ & $\begin{array}{l}0.005 \\
(0.18)\end{array}$ & $\begin{array}{l}0.004 \\
(0.11)\end{array}$ & - & $\begin{array}{l}-0.013 \\
(-0.42)\end{array}$ & $\begin{array}{l}-0.015 \\
(-0.46)\end{array}$ \\
\hline \multicolumn{10}{|c|}{ Tests of whether the coefficients of $\sigma_{i t} * 1_{\{08-11\}}$ and $\sigma_{i t} * 1_{\{04-07\}}$ are equal } \\
\hline Test & $\mathrm{F}(1,58)$ & $\chi^{2}(1)$ & $\chi^{2}(1)$ & $\mathrm{F}(1,58)$ & $\chi^{2}(1)$ & $\chi^{2}(1)$ & $\mathrm{F}(1,58)$ & $\chi^{2}(1)$ & $\chi^{2}(1)$ \\
\hline Value & $16.19^{* * *}$ & $7.73^{* *}$ & 3.08 & 0.85 & 2.93 & 1.42 & 2.14 & $6.86^{* *}$ & $7.01^{* *}$ \\
\hline \multicolumn{10}{|c|}{ Sargan test of overidentifying moment restrictions } \\
\hline Test & - & $\chi^{2}(160)$ & $\chi^{2}(167)$ & - & $\chi^{2}(150)$ & $\chi^{2}(135)$ & - & $\chi^{2}(230)$ & $\chi^{2}(238)$ \\
\hline Value & - & $195.3^{*}$ & $205.3^{*}$ & - & 172.4 & 157.3 & - & $301.1^{* * *}$ & $309.9^{* * *}$ \\
\hline \multicolumn{10}{|c|}{ Tests of joint significance of independent variables } \\
\hline $\begin{array}{l}\text { Test } \\
\text { Value }\end{array}$ & $\begin{array}{l}\mathrm{F}(7,58) \\
87.58^{* * *}\end{array}$ & $\begin{array}{l}\chi^{2}(8) \\
397.37^{* * *}\end{array}$ & $\begin{array}{l}\chi^{2}(8) \\
354.2^{* * *}\end{array}$ & $\begin{array}{l}\mathrm{F}(7,58) \\
24.99^{* * *}\end{array}$ & $\begin{array}{l}\chi^{2}(8) \\
37.79^{* * *}\end{array}$ & $\begin{array}{l}\chi^{2}(8) \\
44.08^{* * *}\end{array}$ & $\begin{array}{l}\mathrm{F}(7,58) \\
31.08^{* * *}\end{array}$ & $\begin{array}{l}\chi^{2}(8) \\
149.57^{* * *}\end{array}$ & $\begin{array}{l}\chi^{2}(8) \\
143.2^{* * *}\end{array}$ \\
\hline No. Obs. & 7378 & 5588 & 5588 & 4675 & 3052 & 3052 & 5698 & 4097 & 4097 \\
\hline
\end{tabular}

Table V: This table reports the relationship between investment, $x_{i(t+1)}$, and the cash flow uncertainty measure, $\sigma_{i t}$ around the financial crisis of 2007. Columns I, II, and III for each type of investment report the results from the panel regression model, the dynamic panel model with exogenous $\sigma_{i t}$, and the dynamic panel data model with endogenous $\sigma_{i t}$, respectively. We focus on the subsamples 2004-2007 and 2008-2011 around the crisis. $\sigma_{i t}$ is replaced by two variables $\bar{\sigma}_{i t} 1_{\{04-07\}}$ and $\bar{\sigma}_{i t} 1_{\{08-11\}}$ which are each normalized to have unit variance over the corresponding subsamples. The rest of the variables are defined as in Table I. The estimation is performed in the same manner as described in Tables II- IV. 


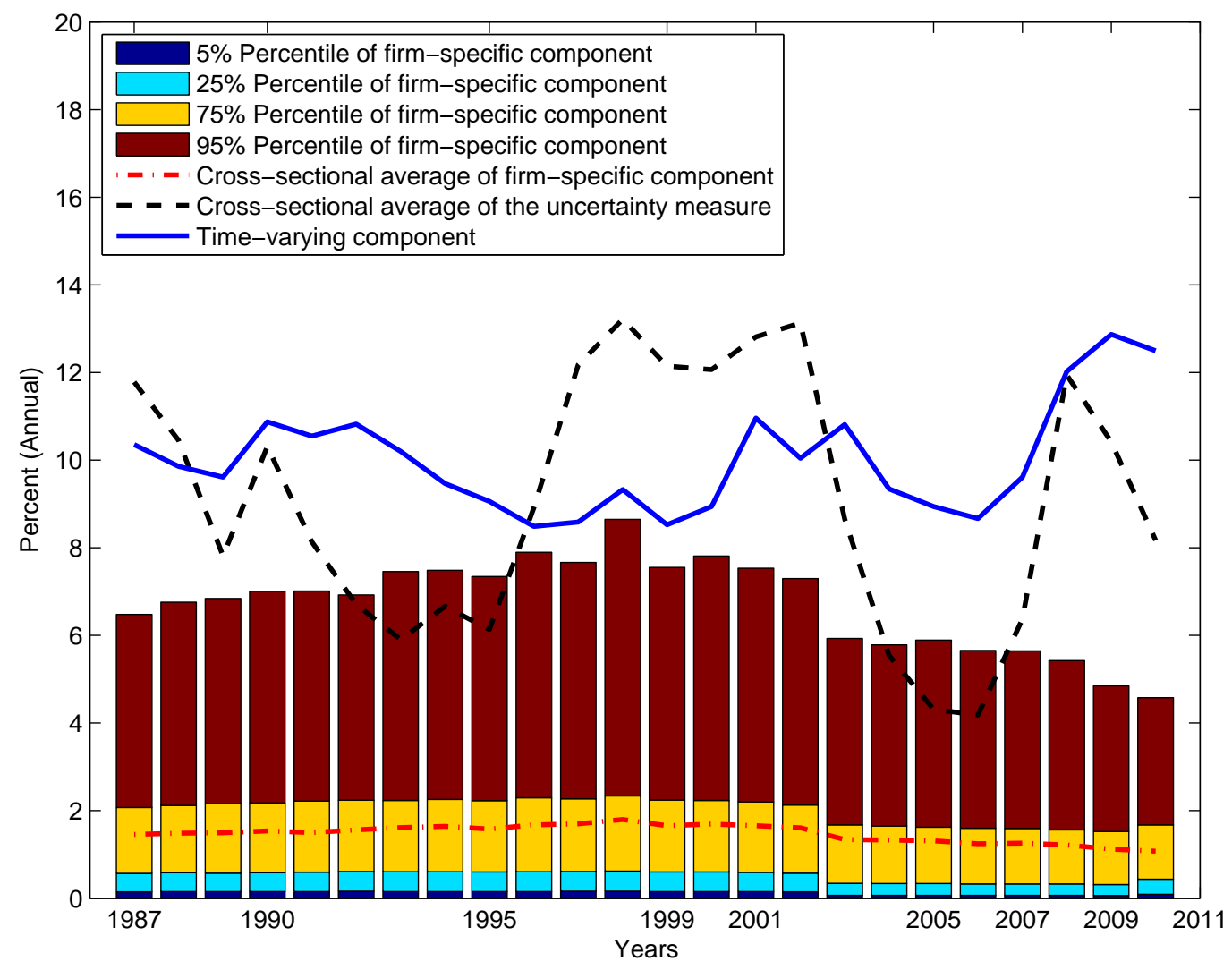

Figure 4: Cash flow uncertainty measure: For each firm we estimate the cash flow uncertainty measure $\sigma_{i t}^{B B D}$ as described in equation (17). This measure is the product of a time-invariant firm-specific component, $\sqrt{\eta_{i}}$, and a firm-independent time-varying component, $\sqrt{B B D}_{t}$, where $B B D_{t}$ is the policy uncertainty index of Baker, Bloom and Davis (2011). The vertical bars in the plot show the distribution $(5 \%, 25 \%, 75 \%$, and $95 \%$ percentiles) of the firm-specific component over time. The dotted line between the 25 and 75-percentiles is the cross-sectional average of these firm-specific components. The continuous line shows the time-varying component, $\sqrt{B B D}$, divided by 100 . Finally, the dashed line shows the cross-sectional average of $\sigma_{i t}$ (the product of the cross-sectional average of the firm-specific component and the time-varying component $\sqrt{B B D}_{t}$ ). 


\begin{tabular}{|c|c|c|c|c|c|c|}
\hline \multirow{3}{*}{$\begin{array}{l}\begin{array}{l}\text { Independent } \\
\text { variables }\end{array} \\
g_{t}^{G D P}\end{array}$} & \multicolumn{6}{|c|}{ Dependent variable $x_{i(t+1)}$} \\
\hline & \multicolumn{2}{|c|}{$\operatorname{Tang}_{i(t+1)}$} & \multicolumn{2}{|c|}{$\operatorname{Intan}_{i(t+1)}$} & \multicolumn{2}{|c|}{$E m p_{i(t+1)}$} \\
\hline & $\begin{array}{c}0.608^{* * *} \\
(11.53)\end{array}$ & $\begin{array}{c}0.412^{* * *} \\
(4.08)\end{array}$ & $\begin{array}{l}0.121 \\
(0.91)\end{array}$ & $\begin{array}{l}0.029 \\
(0.11)\end{array}$ & $\begin{array}{c}0.319^{* * *} \\
(3.97)\end{array}$ & $\begin{array}{l}-0.255 \\
(-1.59)\end{array}$ \\
\hline$\sigma_{i t}^{B B D}$ & $\begin{array}{c}-0.304^{* * *} \\
(-4.26)\end{array}$ & $\begin{array}{c}-0.191^{*} \\
(-2.06)\end{array}$ & $\begin{array}{l}-0.302^{*} \\
(-2.21)\end{array}$ & $\begin{array}{l}-0.285^{*} \\
(-2.03)\end{array}$ & $\begin{array}{c}-0.475^{* * *} \\
(-3.84)\end{array}$ & $\begin{array}{c}-0.493^{* * *} \\
(-3.34)\end{array}$ \\
\hline $\mathrm{MA}_{i t} / \mathrm{BA}_{i t}$ & $\begin{array}{c}0.022^{* * *} \\
(5.02)\end{array}$ & $\begin{array}{c}0.019^{* * *} \\
(4.27)\end{array}$ & $\begin{array}{c}0.020^{* *} \\
(2.84)\end{array}$ & $\begin{array}{l}0.011 \\
(1.89)\end{array}$ & $\begin{array}{c}0.042^{* * *} \\
(7.17)\end{array}$ & $\begin{array}{c}0.027^{* * *} \\
(6.75)\end{array}$ \\
\hline $\mathrm{CF}_{i t} / \mathrm{K}_{i(t-1)}$ & $\begin{array}{c}0.010^{* * *} \\
(4.03)\end{array}$ & $\begin{array}{c}0.009^{* *} \\
(3.30)\end{array}$ & $\begin{array}{l}0.004 \\
(0.70)\end{array}$ & $\begin{array}{l}0.002 \\
(0.62)\end{array}$ & $\begin{array}{c}0.007^{*} \\
(2.14)\end{array}$ & $\begin{array}{l}0.004 \\
(1.72)\end{array}$ \\
\hline $\mathrm{Ca}_{i t} / \mathrm{BA}_{i t}$ & $\begin{array}{c}0.016^{* * *} \\
(6.32)\end{array}$ & $\begin{array}{c}0.015^{* * *} \\
(5.52)\end{array}$ & $\begin{array}{l}0.004 \\
(0.83)\end{array}$ & $\begin{array}{c}0.014^{* * *} \\
(3.97)\end{array}$ & $\begin{array}{l}0.008^{*} \\
(2.44)\end{array}$ & $\begin{array}{c}0.011^{* * *} \\
(3.79)\end{array}$ \\
\hline $\mathrm{BD}_{i t} / \mathrm{BA}_{i t}$ & $\begin{array}{c}-0.170^{* * *} \\
(-4.87)\end{array}$ & $\begin{array}{c}-0.112^{* *} \\
(-3.04)\end{array}$ & $\begin{array}{l}0.162 \\
(1.85)\end{array}$ & $\begin{array}{l}0.018 \\
(0.19)\end{array}$ & $\begin{array}{l}0.037 \\
(0.60)\end{array}$ & $\begin{array}{l}-0.083 \\
(-1.49)\end{array}$ \\
\hline$x_{i t}$ & $\begin{array}{c}0.249^{* * *} \\
(19.76)\end{array}$ & $\begin{array}{c}0.250^{* * *} \\
(19.55)\end{array}$ & $\begin{array}{c}0.071^{* * *} \\
(5.29)\end{array}$ & $\begin{array}{c}0.052^{* * *} \\
(4.13)\end{array}$ & $\begin{array}{c}0.029^{*} \\
(2.28)\end{array}$ & $\begin{array}{l}0.011 \\
(0.88)\end{array}$ \\
\hline \multicolumn{7}{|c|}{ Sargan test of overidentifying moment restrictions } \\
\hline Test & $\chi^{2}(1102)$ & $\chi^{2}(832)$ & $\chi^{2}(534)$ & $\chi^{2}(1129)$ & $\chi^{2}(723)$ & $\chi^{2}(1129)$ \\
\hline Value & $1268.7^{* * *}$ & $948.8^{* *}$ & $694.9^{* * *}$ & $1258.9^{* *}$ & $939^{* * *}$ & $1235.7^{*}$ \\
\hline \multicolumn{7}{|c|}{ Tests of joint significance of independent variables } \\
\hline $\begin{array}{l}\text { Test } \\
\text { Value }\end{array}$ & $\begin{array}{c}\chi^{2}(7) \\
1410.7^{* * *}\end{array}$ & $\begin{array}{c}\chi^{2}(29) \\
1727.3^{* * *}\end{array}$ & $\begin{array}{c}\chi^{2}(7) \\
73.5^{* * *}\end{array}$ & $\begin{array}{c}\chi^{2}(25) \\
185.4^{* * *}\end{array}$ & $\begin{array}{c}\chi^{2}(7) \\
276.6^{* * *}\end{array}$ & $\begin{array}{c}\chi^{2}(28) \\
603.8^{* * *}\end{array}$ \\
\hline Time dummies & No & Yes & No & Yes & No & Yes \\
\hline No. Obs. & 35207 & 35207 & 21689 & 21689 & 24539 & 24539 \\
\hline
\end{tabular}

${ }^{*} p<0.05,{ }^{* *} p<0.01,{ }^{* * *} p<0.001$

Table VI: This table reports the relationship between investment, $x_{i(t+1)}$, and the alternative cash flow uncertainty measure, $\sigma_{i t}^{B B D}$. This measure of cash flow uncertainty is constructed using the policy uncertainty index of Baker, Bloom and Davis (2011). For each type of investment, columns '(I)' and '(II)' report the results from a dynamic panel data model with or w/o time-fixed effects, where $\sigma_{i t}^{B B D}$ is assumed exogenous while the rest of the variables are assumed endogenous. All specifications include the following additional explanatory variables: $g_{t}^{G D P}, \mathrm{MA}_{i t} / \mathrm{BA}_{i t}, \mathrm{Ca}_{i t} / \mathrm{BA}_{i t}, \mathrm{CF}_{i t} / \mathrm{K}_{i(t-1)}$, and $\mathrm{BD}_{i t} / \mathrm{BA}_{i t}$. These variables are defined in Table I. In addition, all specifications include firm-fixed effects, and errors are clustered by industry. Reported coefficients are estimated via GMM using the method in Arellano and Bond (1991). For all columns, robust $\mathrm{t}$-statistics are reported in parentheses. 


\begin{tabular}{ccccc}
\hline \hline & \multicolumn{3}{c}{$x_{i(t+1)}$} \\
\cline { 2 - 5 } Year & Tang $_{i(t+1)}$ & $\operatorname{Intan}_{i(t+1)}$ & $E m p_{i(t+1)}$ & $E m p_{i(t+1)}($ Million Jobs $)$ \\
\multicolumn{5}{c}{ Panel A: Change in $x_{i(t+1)}$ when $\sigma_{i t}$ changes } \\
\hline 2009 & $0 \%$ & $0 \%$ & $0 \%$ & 0 \\
2005 & $1.4 \%$ & $1.86 \%$ & $1.87 \%$ & 2.43 \\
2000 & $0.35 \%$ & $0.46 \%$ & $0.47 \%$ & 0.61 \\
1995 & $1.37 \%$ & $1.81 \%$ & $1.82 \%$ & 2.37 \\
1990 & $0.53 \%$ & $0.70 \%$ & $0.71 \%$ & 0.92 \\
\multicolumn{5}{c}{ Panel B: Change in $x_{i(t+1)}$ when $\sigma_{i t}^{B B D}$ changes } \\
\hline 2009 & $0 \%$ & $0 \%$ & $0 \%$ & 0 \\
2005 & $1.33 \%$ & $1.32 \%$ & $2.07 \%$ & 2.69 \\
2000 & $1.33 \%$ & $1.32 \%$ & $2.07 \%$ & 2.61 \\
1995 & $1.28 \%$ & $1.27 \%$ & $2.01 \%$ & 1.36 \\
1990 & $0.67 \%$ & $0.66 \%$ & $1.05 \%$ & \\
\hline \hline
\end{tabular}

Table VII: This table reports the changes in the average investment and employment measures as average uncertainty changes from the level in 2009 to the levels in one of the following comparison years: 2005, 2000, 1995, and 1990. These estimates are computed as product between the coefficient in front of the cash flow uncertainty measure - column III in Tables II- IV and columns 1, 3, and 5 in Table VI - and the change in the average cash flow uncertainty between the levels in 2009 and the level in one of the comparison years, under the assumption that the distribution of firm-specific coefficients of 2009 remains unchanged for the comparison year. Panel A uses $\sigma_{i t}$ as a measure of cash flow uncertainty, while Panel B uses $\sigma_{i t}^{B B D}$. This latter measure is based on Baker, Bloom and Davis(2011)'s policy uncertainty index. 